\title{
The current state of municipal solid waste landfills in Suceava county and their impact on water and soil
}

\author{
Dumitru MIHĂILĂ ${ }^{{ }^{*}}$, Valeria DIṬOIU' and Petruţ-lonel BISTRICEAN² \\ 1 "STtefan cel Mare" University of Suceava, Department of Geography, Suceava, Romania \\ 2 National Meteorology Administration, CMR Moldova - lasi, Suceava Weather Station, Romania \\ * Correspondence to: Dumitru Mihăilă, Department of Geography, "Stefan cel Mare" University of Suceava,. E-mail: \\ dumitrum@atlas.usv.ro.
}

(C)2013 University of Suceava and GEOREVIEW. All rights reserved.

doi: 10.4316/GEOREVIEW.2013.22.1.113

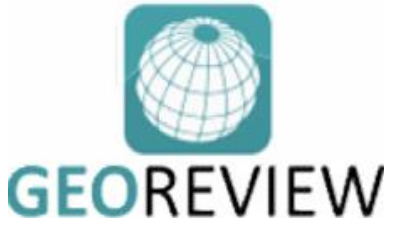

Article history

Received: July 2013

Received in revised form: July

2013

Accepted: August 2013

Available online: September

2013

\begin{abstract}
The location of municipal solid waste (MSW) landfills in inappropriate places is a serious risk to the quality of all environmental factors. These waste disposal sites can become major sources of chemical pollution and biological contamination of soil, groundwater and surface waters due to the high content of heavy metals and organic substances with low biodegradation rate.

The paper discusses in detail the issues of the landfill sites territorial distribution in Suceava County (the Mirăuţi landfill, located in the adjacent area of Suceava city and the Gura Humorului, Radauti, Siret, Campulung Moldovenesc, Fălticeni and Vatra Dornei urban landfills), together with a review of the technical data of the landfills, as well as an evaluation of the qualitative and quantitative effects they produce on the landscape, soil and groundwater quality.
\end{abstract}

KEY WORDS: chemical pollution, biological contamination, groundwater pollution, alert and intervention thresholds

\section{Introduction}

Soil pollution is a form of pollution difficult to measure and control. One of the main causes of soil contamination is the uncontrolled disposal of waste resulted from various human activities.

MSW's are represented by the solid residues collected from public housing, usually made of paper, plastic, fabric, ceramic, glass, packaging, batteries, tires, oils and food scraps.

Disposal of this waste is acknowledged as generating impact and risk to the environment and public health (Cojocaru, 1995).

As a result of the evolution and growth of population and civilization, leftovers generated by housekeeping and food preparing, to which we may add a significant amount of materials resulted from food packaging and even some damaged household items, are no longer considered "trash", but a genuine secondary resource of feedstock and recyclable materials (Bularda et al., 1992; Rojanschi and Bran, 2002). 
Reducing waste volume and protecting natural resources involve the deployment of selective waste collection, recovery and recycling of reusable waste.

The concept of the waste management options hierarchy, developed in the past 20 years, also included in the European Union Waste Management Strategy, recommends the following order of prioritizing waste management actions: waste prevention - including the minimization of the generated amount, recovery, waste recycling and reuse, energy recovery by incineration and finally disposal.

The main objective of the new Framework Directive, Directive no. 2008/98/EC on waste, consists in the prevention and reduction of negative environmental impacts caused by waste generation and management, as well as reducing overall effects of natural resources utilization and increasing their efficiency.

Nowadays in Romania, waste disposal is the main option for the elimination of municipal waste, and currently there are no municipal waste incineration equipments.

Local municipal administration has the responsibility for MSW management that should imply separate collection, transportation, dismantling, recovery and final disposal of such waste.

The composition of municipal waste is of particular importance, defining the potential for waste recovery and helping establish collection systems.

Analyzing the morphological structure of municipal solid waste in Suceava County, we find that the largest share is represented by biodegradable waste. The biodegradable fraction of MSW (which in Romania is a major component) includes: biodegradable waste produced by households and public food industry, vegetable garden and park waste, biodegradable waste from markets, the biodegradable component of street waste, sludge from municipal wastewater, paper/cardboard waste (of poor quality, that cannot be recycled).

None of the seven MSW disposal sites of the county, classified according to the types of waste contained as non-hazardous locations („, b" Class) is in accordance with the provisions of Directive no. 1999/31/EC on waste disposal.

MSW disposal sites may cause serious adverse effects both on environmental factors such as air, water or soil and vegetation, wildlife and people's health over large areas (Rojanschi et al., 2002; Manfredi et al., 2010). The following negative effects may therefore occur:

- unaesthetic landscape changes;

- air pollution with odors, toxic gaseous emissions and particulate pollutants carried by wind;

- groundwater contamination with toxic substances that leach due to soil permeability;

- soil degradation, proportional with increasing of disposed waste layer depth containing organic substances, detergents, pesticides, heavy metals, pathogens, etc., and changes in soil fertility and biocenoses composition in the neighbouring fields;

- permanent physic-chemical and biological contamination of surface waters flowing in the vicinity of the landfills with biodegradable or low biodegradable organic compounds, mineral salts, heavy metals; maximum contamination values are recorded during flood intervals, when waste is washed away by water;

- the presence of diseases carriers such as rodents and some insects. 


\section{The current situation of MSW landfills. Prospects for the following years}

According to the commitments made by Romania in the negotiation process of Chapter 22 Environment, on the implementation of the Directive for waste disposal, transposed into our legislation by Government Resolution No. 349/2005, transition periods for non-compliant MSW landfills were obtained (for Romania as a whole and for its administrative subdivisions - in our case: Suceava County) (located within the territory according to Fig. 1).

Currently, Suceava County receives technical assistance under the framework of the ISPA Programme no. 2005/RO/16/P/PA/001-04 for the implementation of the project „Integrated management system of municipal waste in Suceava County" (County Waste Management Plan for Suceava).

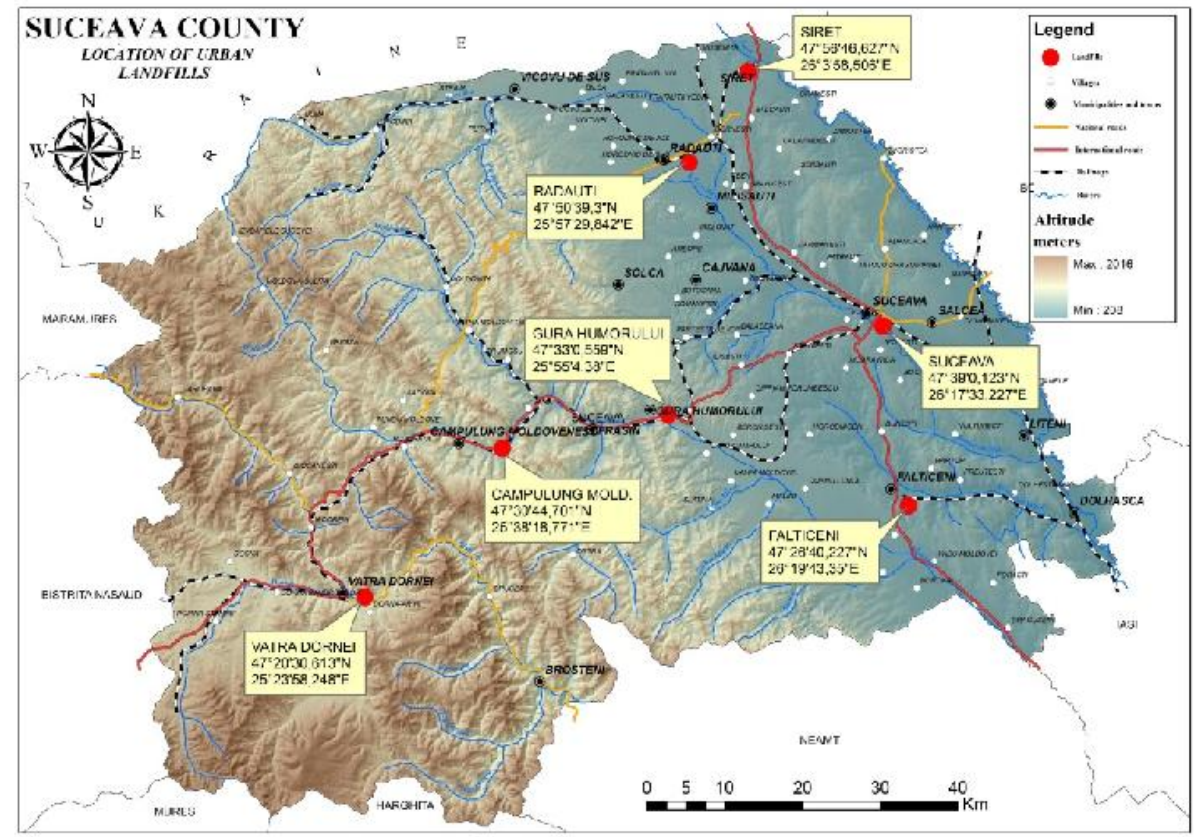

Figure 1. Location of MSW landfills in Suceava County.

According to the environmental agreement no. 9/12.10.2009, revised on 23.03.2010, issued by A.R.P.M. Bacau, the following clauses are proposed:

- closure of 7 non-compliant urban landfills (Suceava, Radauti, Gura Humorului, Falticeni, Campulung Moldovenesc, Siret, Vatra Dornei);

- construction of two compliant landfills (Moara - $5399980 \mathrm{~m}^{3}$ and Pojorata $352500 \mathrm{~m}^{3}$ );

- establishment of one waste sorting station at the Moara landfill $(6700$ tones/yr of paper/cardboard waste, 11220 tones/yr plastic/metal waste); - establishment of five transfer stations: Radauti - 40600 tones/yr; Fălticeni - 27544 tones/yr, Campulung Moldovenesc 11200 tones/yr, Gura Humorului - 27544 tones/yr (only enlargement in this particular case, because the transfer station was constructed with Phare ESC 2004 funding), Vatra Dornei (only collection center, because the transfer station was constructed with Phare ESC 2004 funding) and of 44,000 individual composting units; 
- construction and equipment of waste collection platforms in rural areas with centres for glass and plastic/metal collection;

- construction and equipment of waste collection platforms in urban areas with centres for glass collection, but also for plastic/metal and paper /cardboard collection.

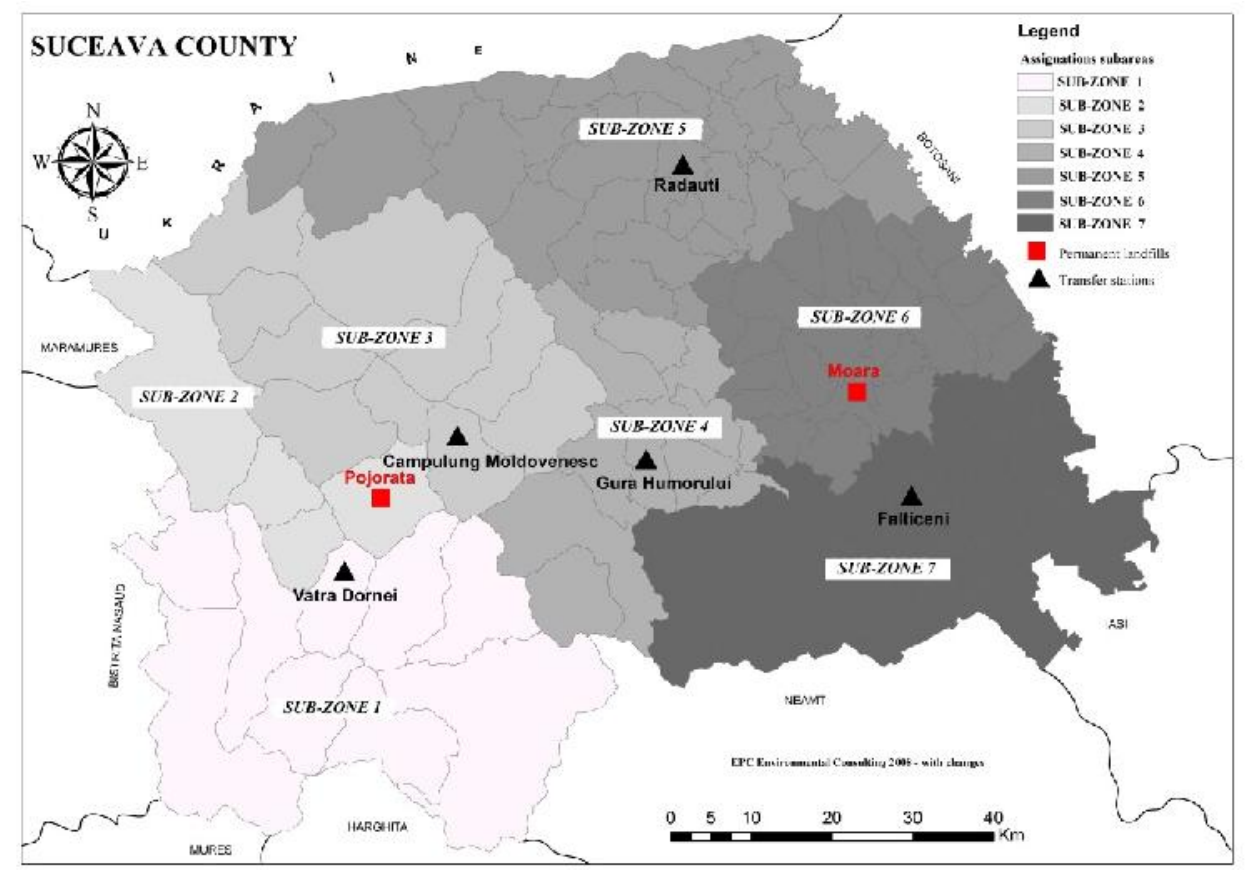

Figure 2. Waste collection sub-zones and future MSW selection and disposal locations in Suceava County.

By means of this project, financed by the EU, the county will be divided into 7 sub zones for waste collection - Figure 2, two waste storage areas (Moara and Pojorâta) will be built and functional by 2014, the transfer stations (Radauti, Fălticeni, Campulung Moldovenesc, Vatra Dornei and Gura Humorului) and a waste sorting station at Moara landfill are or will be constructed / extended.

Until the implementation of the integrated system in Suceava county, the county's municipal waste has been disposed in the existing functional landfills (Fălticeni, Gura Humorului and Campulung Moldovenesc), as well as in the functional landfills of the neighbouring counties (Botosani, Darabani and Targu Neamt).

Currently, dispensations have been obtained for urban waste disposal on the old, non-functional landfills, waste which will be afterwards transferred to the compliant landfills in Moara and Pojorâta, after these become functional in 2014.

\section{Data and methods used}

The elaboration of the current paper is based on the following information:

- for preparing the maps with the territorial distribution of existing waste disposal sites in Suceava County, the ArcGIS v9.3 software package was used. Raster information was 
transformed according to the rectangular coordinate system of the study area, followed by the identification and creation of the vector spatial data system required to draw these maps. As raster support, we used the 2006 ortophotoplans and the satellite images from 2012.

- information on the MSW production (types of produced and collected waste), provided by the sanitation operators and managers of landfills, but based on estimates and not on precise data obtained by weighing;

- the results of physical - chemical analyses for groundwater and soil samples collected from areas bordering municipal landfills;

- calculation of indices for air, water and soil pollution, in order to determine the need for ecological restoration of non-compliant landfills.

\section{The territorial distribution of existing waste disposal sites in Suceava County}

\subsection{The MSW landfill of the Suceava City}

The municipal waste storage platform in Suceava is located on public land, belonging to the Ipoteşti local administration, between the right bank of the Suceava River and the Cetatea forest edge, $500 \mathrm{~m}$ eastward of the Suceava city. It occupies an area of approximately 11.6 hectares. The landfill's height in some points reaches $8-10 \mathrm{~m}$, and in others $2-3 \mathrm{~m}$. The Mirauti nonhazardous landfill of the Suceava municipality belongs to class „b", CAEN code 9001, which allows municipal waste disposal up to $200000 \mathrm{~m}^{3} / \mathrm{yr}$.

The platform neighbors with the Suceava River in the N, a forested area in the S, with Cetatii Creek and an access road in the E and with another forested area in the W (Fig. 3).

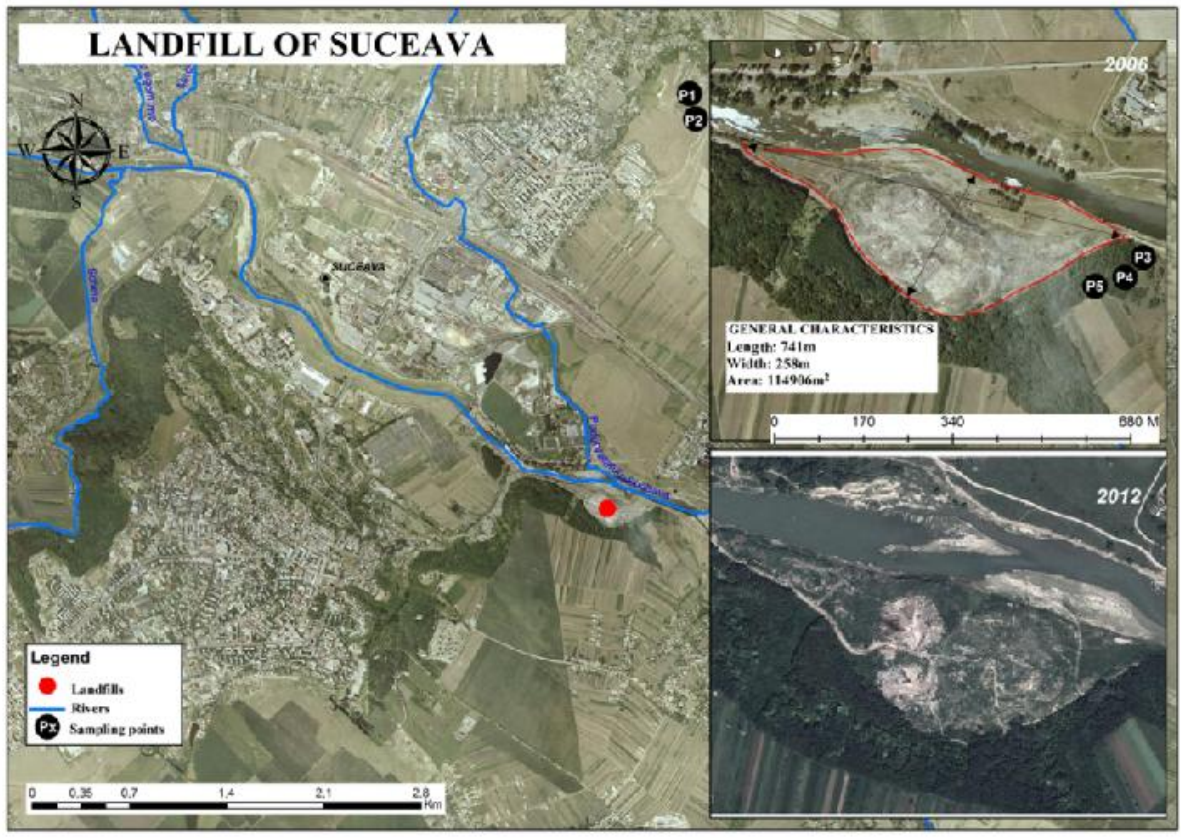

Figure 3. The municipal waste landfill in the Suceava city. 
The landfill site is located in the floodplain of the Suceava River - a subunit of the Suceava Plateau, on the right bank of the above mentioned river and at a distance of $200 \mathrm{~m}$ from the closest households/human dwellings.

The landfill is incorrectly positioned and moreover, it is not enclosed - Fig. 4. Both municipal and industrial waste have been accepted for disposal. Because of the biogas production, waste self ignites, the fire being difficult to extinguish. At floods, there is the risk that some of the waste reach the Suceava River, due to the degradation of approximately $100 \mathrm{~m}$ of the river bank protection structures.

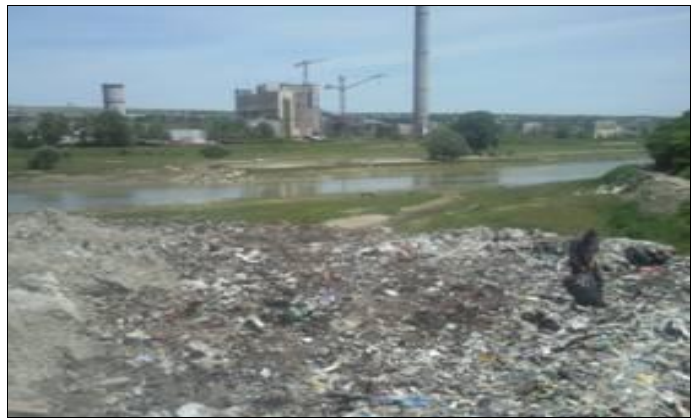

Figure 4. The MSW landfill in Suceava, southwestern view (photo by Ditoiu Valeria, 06.2012).

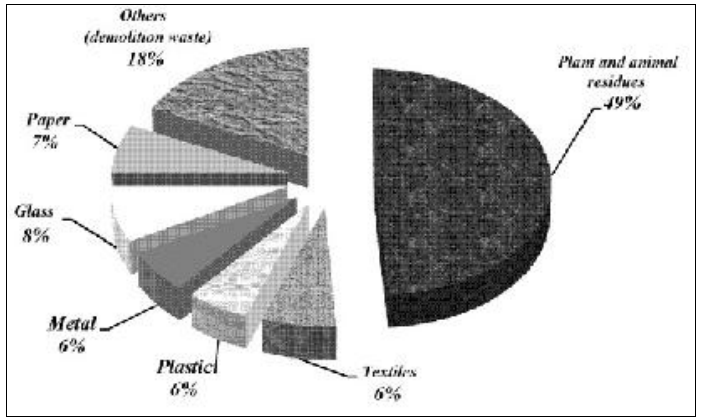

Figure 5. Components of the municipal waste in Suceava (\%) - multi-annual statistical data (source: Environmental Protection Agency Suceava).

The Suceava city waste disposal platform was opened in 1972. The platform development followed three periods. Between 1972 and 1982, waste was disposed on a surface of $18000 \mathrm{~m}^{2}$ (zone 1), with a total amount of $250000 \mathrm{~m}^{3}$. In the period $1983-1993$ the area used for waste storage increased to $25000 \mathrm{~m}^{2}$ (zone 2), with an amount of collected and stored waste of 375000 $\mathrm{m}^{3}$. During the third period $1994-2005$, waste was disposed on an area of $72000 \mathrm{~m}^{2}$ (zone 3), and the amount of disposed waste increased to $1025000 \mathrm{~m}^{3}$.

From 31.12.2008, waste disposal activities ceased on this platform. The average annual urban waste amount collected in Suceava equals approx. $120000 \mathrm{~m}^{3}$.

The components of urban waste collected in the Suceava City are: biodegradable - $49 \%$, materials resulting from demolition - $18 \%$, paper $-7 \%$, glass $-8 \%$, metals $-6 \%$, plastic $-5.5 \%$ and textiles $6 \%$ - Fig. 5.

\subsection{The MSW landfill of Radauti municipality}

Radauti town has a mixed landfill of industrial and household waste, constructed in 1983, and located $5 \mathrm{~km}$ from the urban perimeter, on the County Road Radauti - Satu-Mare - Fig. 1 and 6.

The landfill covers an area of 4.43 ha and has a capacity of $250000 t$. The total amount of waste to be disposed annually was about $13200 t$. By the end of 2009 , solid waste collected in Radauti was disposed of in a controlled manner, using two methods. A first method consisted in the disposal at the landfill site, located in the eastern part of the town. Since 2010, waste has partly been eliminated by sorting and recycling. 


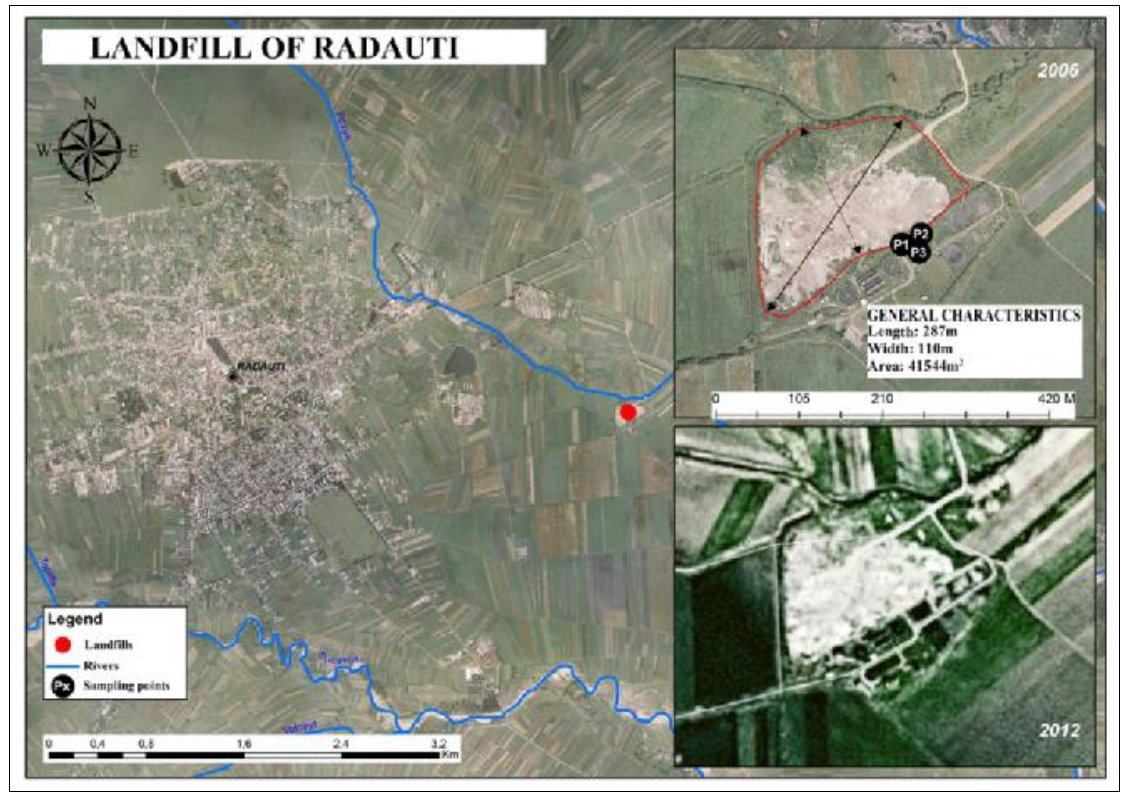

Figure 6. The Radauti municipal landfill location.

\subsection{The MSW landfill of Fălticeni municipality}

The Waste landfill is located near the city, at a distance of $3.5 \mathrm{~km}$ from city center - Fig. 7, with an area of $10000 \mathrm{~m}^{2}$ (1ha). Each year, over 23,500 tons of waste have been disposed of there. According to the Governmental Resolution No. 349/2005 on waste disposal, the Antileşti Fălticeni landfill was closed in July 2010, due to reaching of storage capacity.

The landfill perimeter is not properly fenced - Fig. 8d, c, and the platform has no waste collecting and water treatment systems, which causes water to infiltrate into the soil.

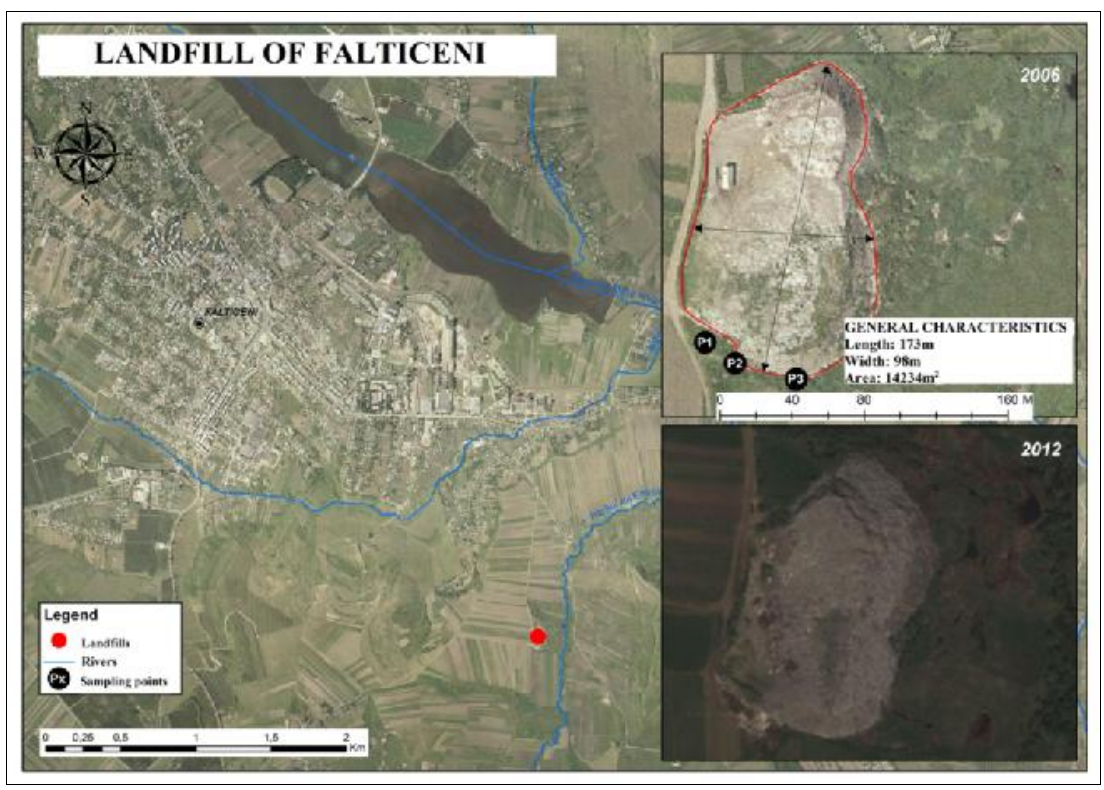

Figure 7. The Fălticeni municipal landfill. 


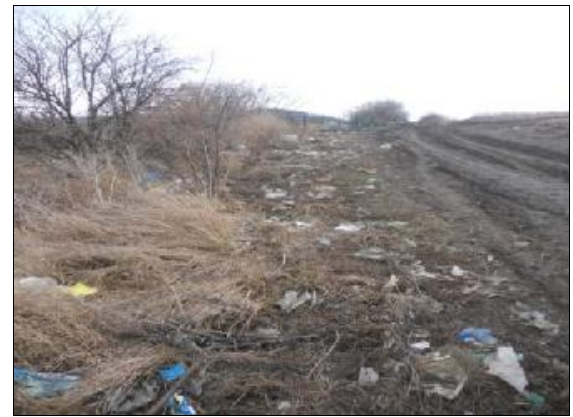

a.

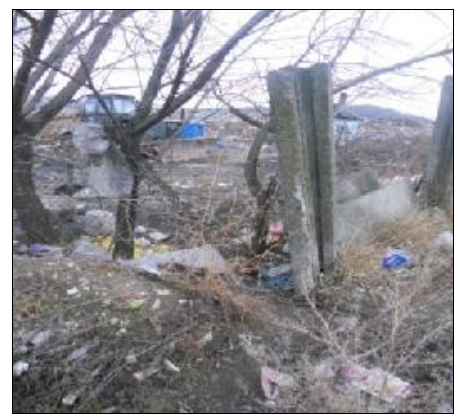

c.

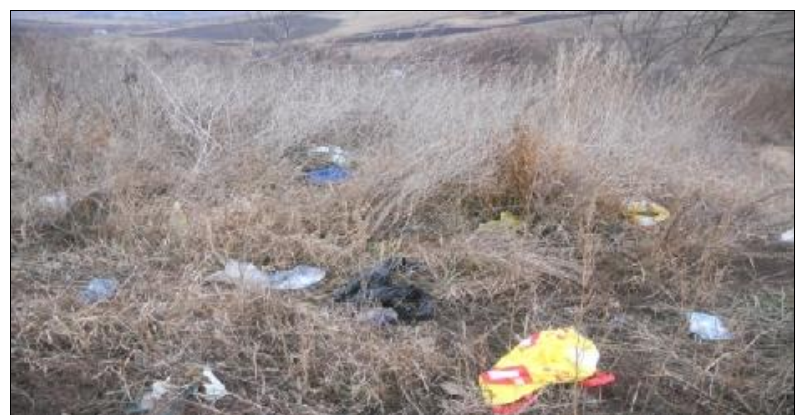

b.

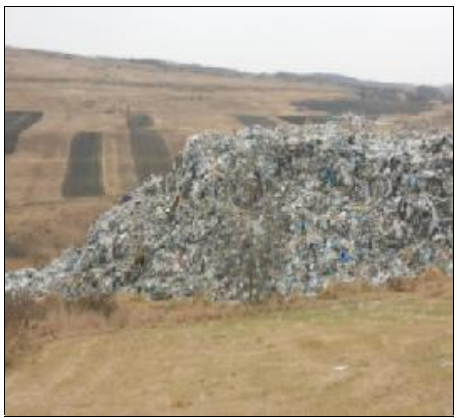

d.

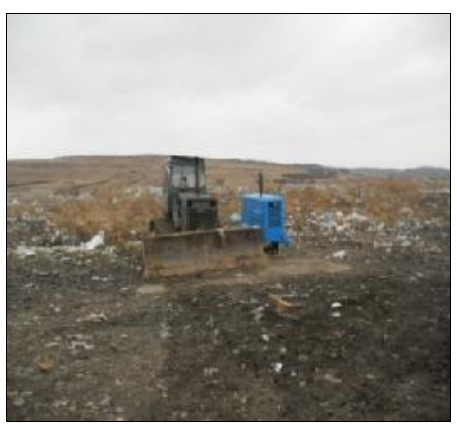

C.

Figure 8. The Antilesti - Falticeni landfill (photo by Zoita Anisoara, 05. 2011)

In the landfill platform area, no selective collection technologies have been applied to facilitate ecological reconstruction of the area, reusable materials have not been rendered valuable, and biodegradable materials have not been separated from non-biodegradable materials.

Another hazard is represented by combustible waste (cardboard, plastic, paper, leather, wood, textiles) and moreover, fermentation of organic waste produces biogas that can fuel air polluting combustion. Due to inadequate location of the landfill, household waste is driven away by air currents and scattered on the neighboring fields - Figs $8 a$ and $b$.

The landfill is improperly surrounded by several concrete plates - Fig. 8c. On the southern side, the slope has a height of 5 meters, it is not stabilized and therefore hazardous, as sliding may occur anytime; on the northern side, the landfill is not enclosed and moreover, has no geophysical stability, which leads to waste sliding and decompaction.

\subsection{The Hurghis MSW landfill of the Campulung Moldovenesc municipality}

The Hurghiş non-hazardous MSW landfill from Campulung Moldovenesc, Suceava County, is located at approx. $1 \mathrm{~km}$ eastward of the residential area - Fig. 9 and belongs to the "b" class, with an area of $1.62 \mathrm{ha}$, and an annual capacity of over 19000t.

The Hurghiş landfill became functional in 1990, with a projected capacity of $115800 \mathrm{~m}^{3}$, and an area of 2.14 ha.

The Hurghis platform is not made of concrete / asphalt and has almost no fencing - Fig. 9. 

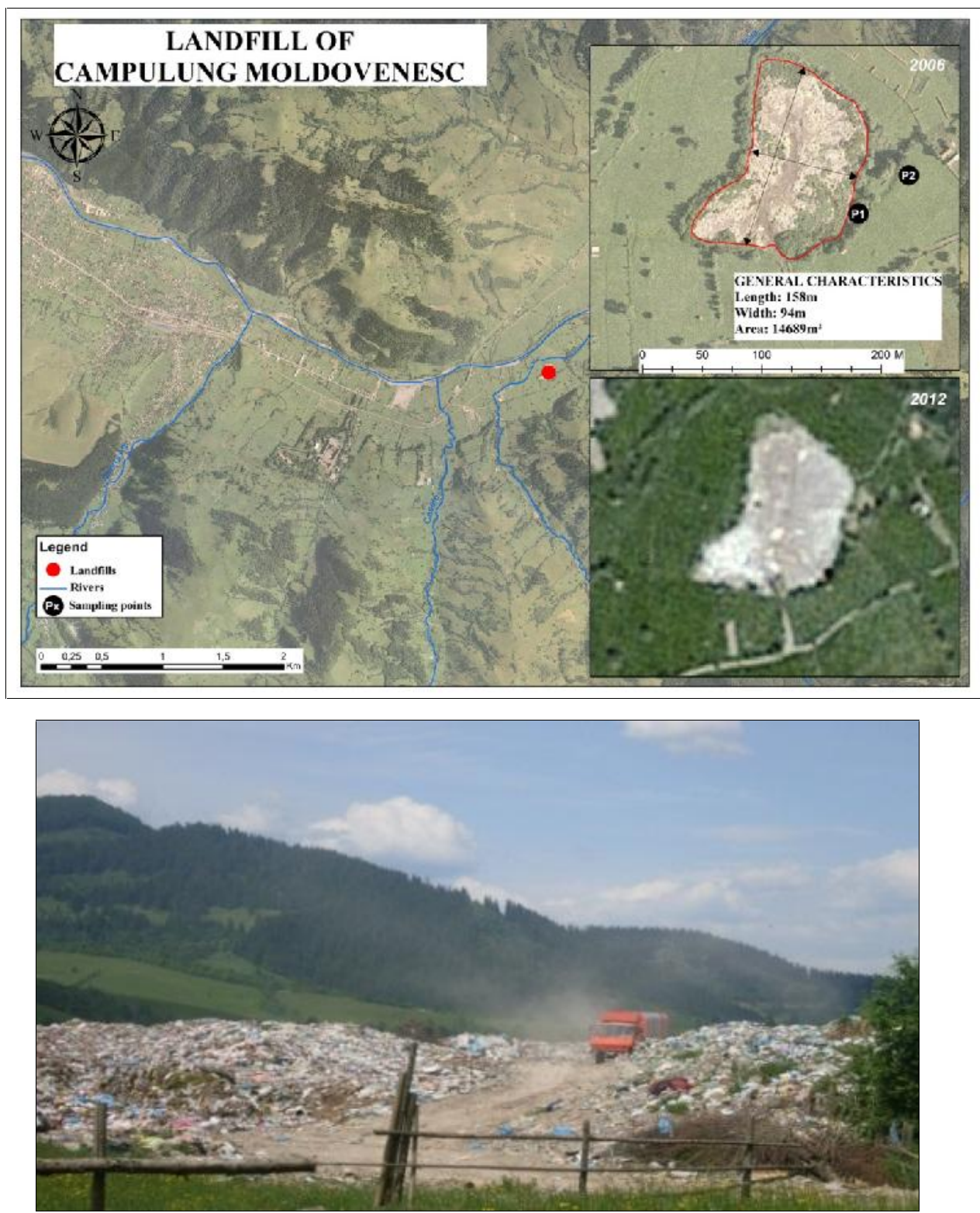

Figure 9. The Hurghis landfill near Campulung Moldovenesc (photo by Ditoiu Valeria, 06.2011).

\subsection{The urban solid waste landfill of Gura Humorului city}

It is a non-hazardous waste landfill belonging to "b" class, with an area of 2,126 ha, located eastward at approx. $800 \mathrm{~m}$ distance from the built area - Fig. 10. The location allows the disposal of approx. $16000 \mathrm{~m}^{3} / \mathrm{yr}$, equivalent to $14000 \mathrm{t}$ of municipal waste to be disposed of annually.

The landfill is poorly fenced - Figure. 11a, and waste collection is not selective - Fig. 11a and b. 


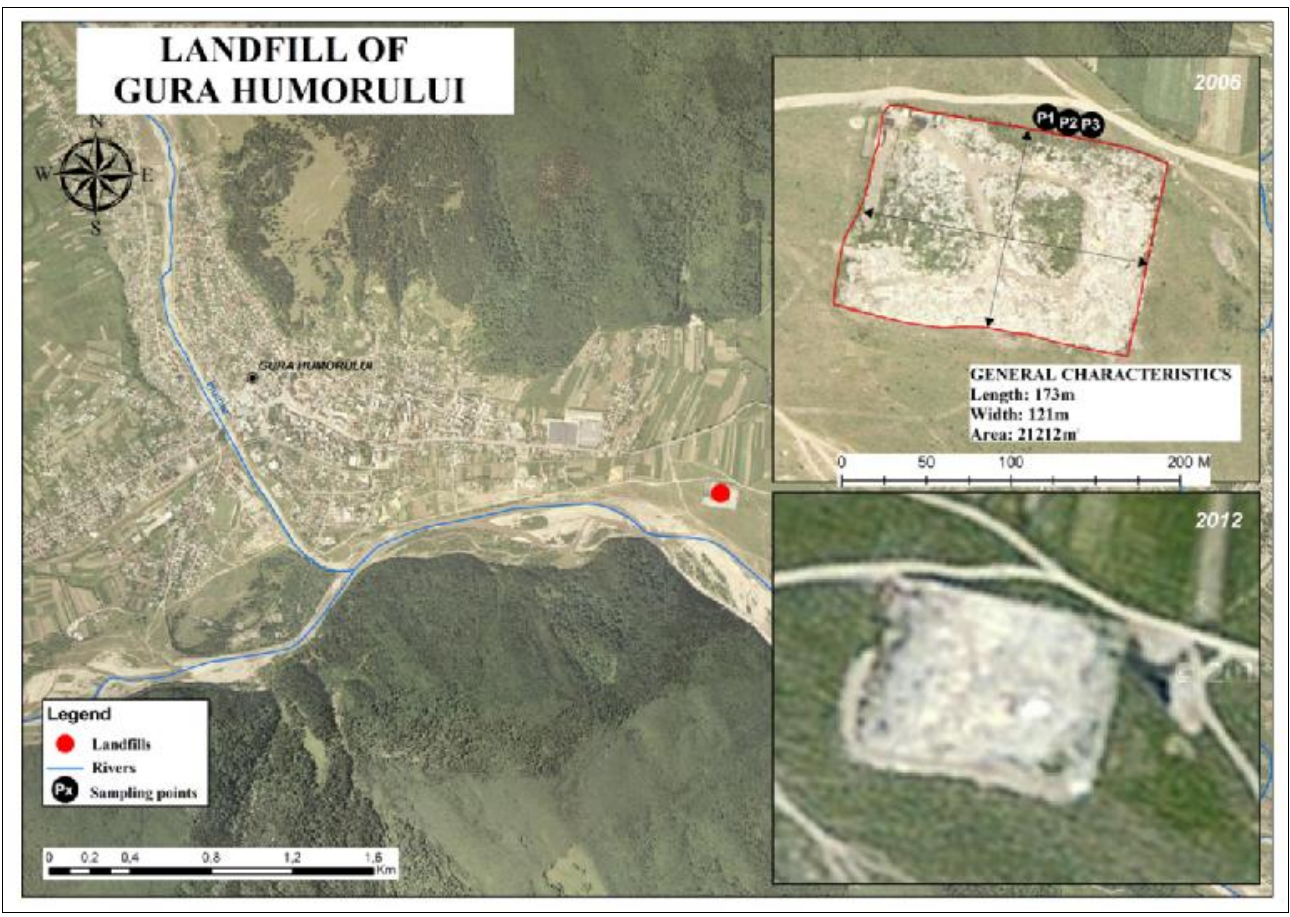

Figure 10. The Gura Humorului municipal landfill.

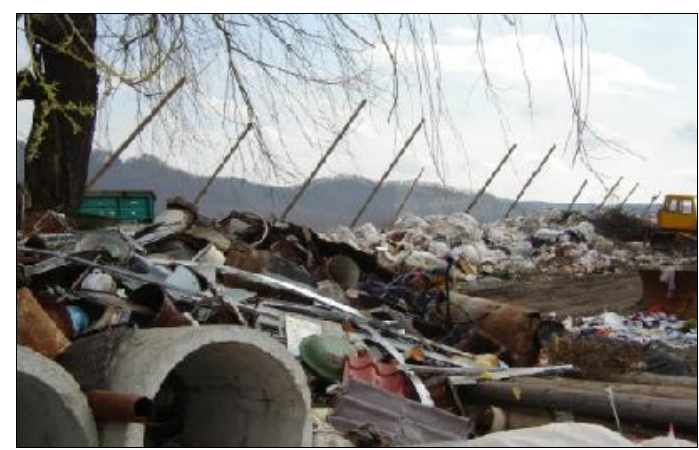

a.

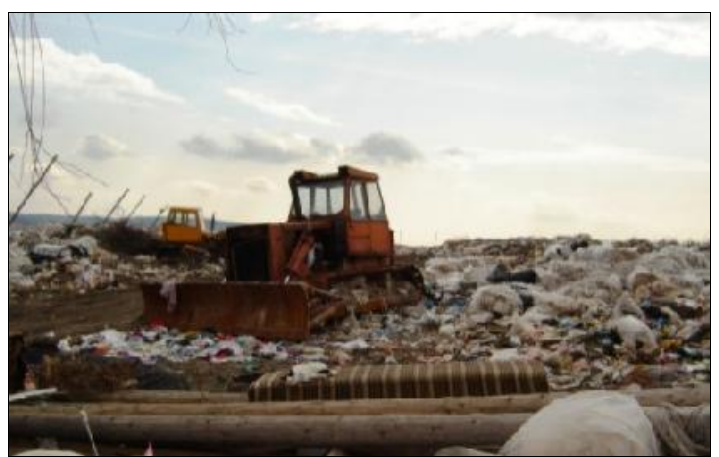

b.

Figures 11a, b. The Gura Humorului solid waste landfill (photos by Semeniuc Marius, 05.2011)

\subsection{The urban solid waste landfill of Siret town}

In 1970, the urban waste landfill became functional, on a plateau area of about 0.8 - 1ha located on the Horait Hill, south-west of the town, at 500 meters distance from the closest households Fig. 12. This landfill is not properly developed, but placed on unproductive land - Fig. 12. Both household and industrial waste has been disposed here over time.

Since its opening and until its closure in 2008 , the management of the landfill was performed by the Siret local administration. With the landfill closure, a post-closure period started, which included the implementation of a monitoring and environmental cleaning program of the area. Currently, the only waste type that has been approved to be disposed of on the landfill is construction waste (rubble, brick fragments etc.). Since this new destination of the landfill was set, about 4700 t of waste have been annually disposed on the platform. 
The former urban landfill of Siret town is located according to the cadastral map on the parcel 36. The main access road crosses the center of the town, on Suceava Street - a downhill slope road, unpaved, directly connecting the town with both the landfill and the agricultural land in the landfill area - Fig. 12b.

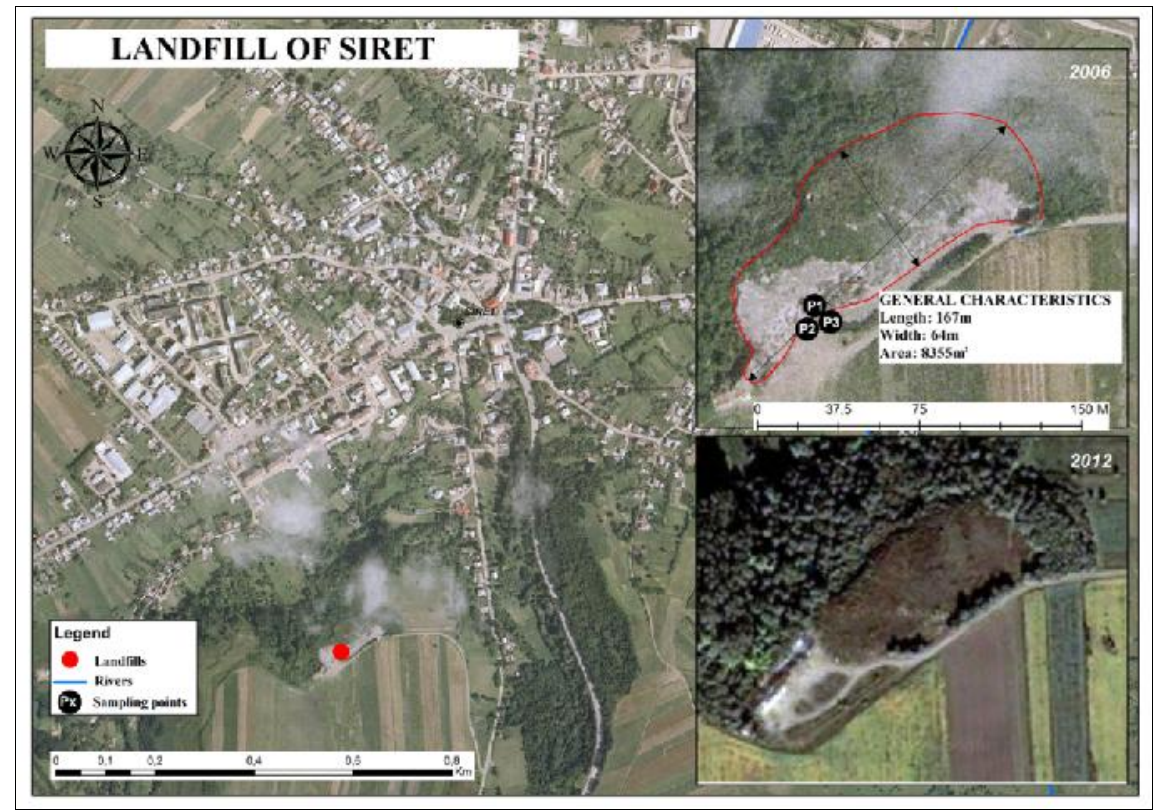

Figure 12a. The urban waste landfill of the Siret town (photo by Barbuta Razvan, 05.2011)

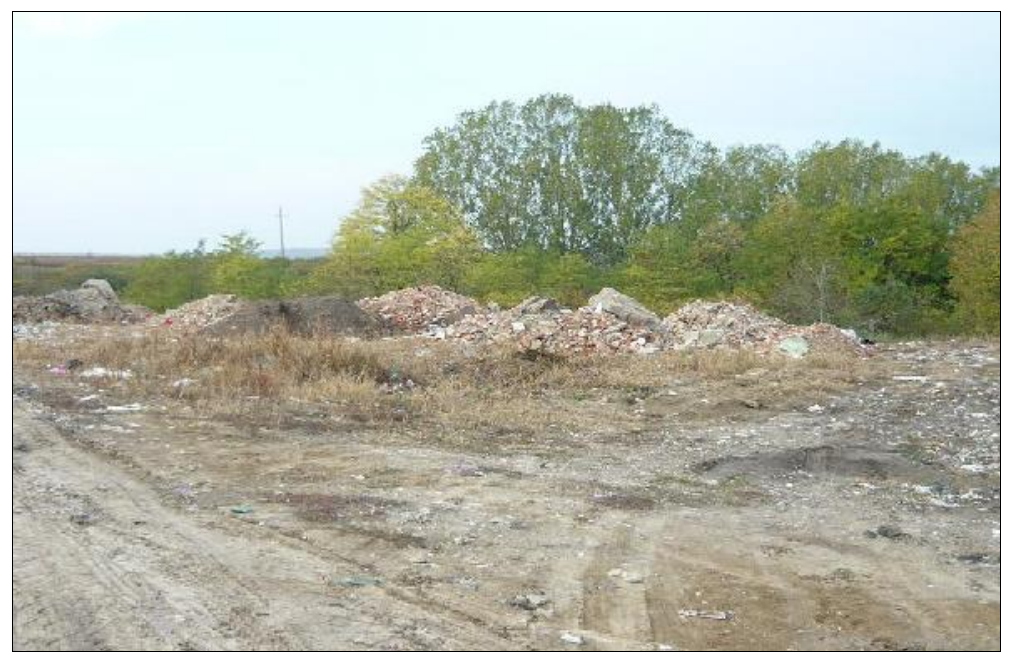

Figure 12b. The urban waste landfill of the Siret town (photo by Barbuta Razvan, 05.2011)

\subsection{The MSW landfill of Vatra Dornei municipality}

The municipal waste disposal platform of Vatra Dornei city (Buliceni landfill) is located on public land, belonging to the Vatra Dornei local administration, with an area of $16980 \mathrm{~m}^{2}, 500 \mathrm{~m}$ northward of the built area. Considering a maximum landfill height of $4 \mathrm{~m}$, the maximum platform capacity is $67920 \mathrm{~m}^{3}$. The platform is located on a hillside area, on the left bank, 50-100 
$\mathrm{m}$ northward of the Bistrita River floodplain - Fig. 13. The nearest major road is DN 17B Vatra Dornei - Brosteni, which crosses the area $1000 \mathrm{~m}$ west of the landfill.

The landfill was opened for use in 1983 and closed in 2005. The distance from residential areas is approximately $1 \mathrm{~km}$. The landfill site is not enclosed. Its projected capacity is $80000 \mathrm{~m}^{3}$, while the utilized capacity equals $60000 \mathrm{~m}^{3}$.

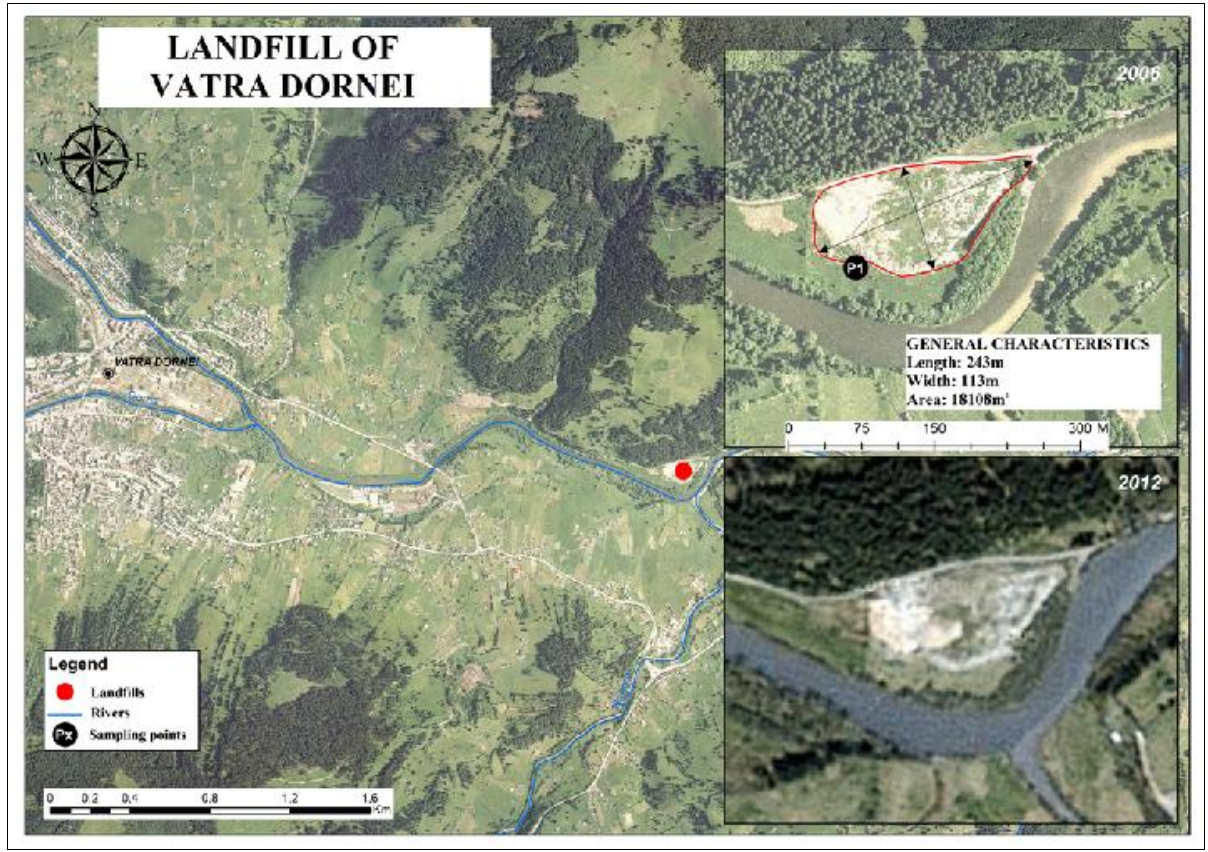

Figure 13. The Vatra Dornei municipal landfill.

The landfill has the following characteristics: lack of platform enclosure (no hedge or prefabricated fence), landfill gas is not collected, no leachate collection system, no monitoring system, no selective waste collection and no recoverable waste collection at the disposal site.

According to their nature, the following shares of different waste categories are estimated and expressed as a percentage: $15 \%$ paper and cardboard, 20\% plastic, $10 \%$ glass, metals $5 \%, 20 \%$ biodegradable waste, construction and demolition waste $15 \%$, textile waste $5 \%$, other $15 \%$.

\section{The effects produced by MSW landfills in Suceava County on environmental factors}

\subsection{Environmental impact assessment by calculation of the pollution index}

This index statistically establishes several thresholds (attention, alert, intervention and risk) for each environmental factor, so that pollution prevention and control strategies should be applied for different values of pollution indices (Macoveanu, 2003; Ditoiu Valeria et al., 2005).

The model places pollution indices on a reliability scale. It sets boundaries between different degrees of pollution and establishes general directions of action on the polluted environmental factor, in different situations. 
The pollution index (PI) has been calculated for each indicator of environmental factors, according to the formula [1]:

$$
I P=\frac{M A C-E C}{M A C+E C} \quad x 100 \quad[1], \text { where: }
$$

- MAC - maximum accepted concentration

- EC - measured or estimated concentration.

According to the pollution index (PI) value, reliability grades can be given for the scale of pollution indices (IP \%) presented in Tab. 1

Table 1. Scale of Pollution indices (PI \%)

\begin{tabular}{|c|c|c|}
\hline $\begin{array}{l}\text { Pollution Index } \\
\text { PI (\%) }\end{array}$ & $\begin{array}{l}\text { Reliability } \\
\text { Grade }\end{array}$ & Effects of pollutants on environmental factors \\
\hline 100 & 10 & Pollution level - Excellent (no pollution) \\
\hline $99,99-70,01$ & 9 & Pollution level - Very good (pollution non-significant for the environment) \\
\hline 70,00 & 8 & Limits for the necessity of quality indices monitoring \\
\hline $69,99-15,01$ & 7 & Pollution level - Good - (low pollution degree) \\
\hline 15 & 6 & $\begin{array}{l}\text { Attention threshold (low pollution, that can produce little disturbance to } \\
\text { the environment) }\end{array}$ \\
\hline $14,99-0,01$ & 5 & $\begin{array}{l}\text { Pollution level - Medium (medium pollution, with possible manifestation of } \\
\text { pollution phenomenon, dangerous for more sensitive living organisms) }\end{array}$ \\
\hline 0,00 & 4 & $\begin{array}{l}\text { Alert threshold (Pollution that is dangerous for living organisms, which } \\
\text { needs the implementation of measures for pollution sources control) }\end{array}$ \\
\hline$(-0,01)-(-14,99)$ & 3 & $\begin{array}{l}\text { Pollution level - Bad (badly affected environment, inadequate for most } \\
\text { living organisms, which needs activity ceasing measures) }\end{array}$ \\
\hline$-15,00$ & 2 & $\begin{array}{l}\text { Intervention threshold (severely affected environment, which needs } \\
\text { measures of activity ceasing and ecological reconstruction) }\end{array}$ \\
\hline$(-15,01)-(-94,99)$ & 1 & $\begin{array}{l}\text { Pollution level - Very bad (significant pollution with destructive effects on } \\
\text { the environment, which requires stopping the polluting source as soon as } \\
\text { possible. Urgent decontamination measures for the environmental factors } \\
\text { are necessary) }\end{array}$ \\
\hline-95 & & Danger threshold \\
\hline$<(-95)$ & $\begin{array}{l}\text { No grades } \\
\text { given }\end{array}$ & $\begin{array}{l}\text { Pollution level - Catastrophic, irreversible for the environmental factors } \\
\text { (pollution is totally destructive for the environmental factors. Urgent } \\
\text { identification measures of the affected area are required, as well as } \\
\text { implementation of ecological reconstruction with creation of new } \\
\text { ecosystems). }\end{array}$ \\
\hline
\end{tabular}

5.1.1. Effects of MSW landfills on soil quality in Suceava, Radauti, Falticeni, Gura Humorului, Campulung Moldovenesc and Siret.

Soil samples were collected from two horizons: $0-5 \mathrm{~cm}$ and $5-30 \mathrm{~cm}$, with a sampling corer. For each horizon of each of the sampling points (marked in the Figure $3,6,7,9,10,12 a, 13$ with the $\mathrm{P}$ symbol and with indices from 1 to 5; example: P1,..., P5) an average sample was collected and analyzed, which was obtained from four soil samples closely located and mixed for homogenization.

The soil samples were prepared in the laboratory according to the ISO 11464/2006 standard.

\section{a. Determination of $\mathrm{pH}$}

$\mathrm{pH}$ was determined according to the SR 7184-13/2001 standard protocol: from air-dried soil sample, crushed and sieved through a $2 \mathrm{~mm}$ mesh opening, an aqueous suspension was prepared with soil/water concentration of $1 / 2,5$ (mass/volume). The activity of hydrogen ions, expressed 
as $\mathrm{pH}$ units was measured in this solution. $\mathrm{pH}$ measurements were performed with a WTW 526 $\mathrm{pH}$ meter, with combined electrode.

\section{b. Determination of metals}

Laboratory sample processing for determinations of heavy metals concentration in soil by atomic absorption spectrometry was performed according to the ISO 11466/1999 standard: we used airdried soil samples, sieved through a sieve with $1.50 \mathrm{~mm}$ mesh opening, of which $1 \mathrm{~g}$ weighted sub-samples were taken. The sub-samples were digested with aqua regia $(2 \mathrm{ml}$ of nitric acid $65 \%$ and $6 \mathrm{ml}$ of $37 \%$ hydrochloric acid), with the help of a MWS3 Berghof microwave digestion device.

The extracts obtained by filtering the mineralized samples were transferred to $100 \mathrm{ml}$ volumetric flasks, where $0.5 \mathrm{~mol} / \mathrm{l}$ nitric acid was added for each flask. For the determination of $\mathrm{Mn}$ concentration, prior to volume equalization in the volumetric flasks, the extracts were added $10 \mathrm{ml}$ of $10 \%$ lanthanum chloride solution and then made up to volume with $0.5 \mathrm{~mol} / \mathrm{l}$ nitric acid.

Measurements of total metals concentrations in the soil (zinc, copper, chromium, cadmium, cobalt, nickel, lead, arsenic) were performed with an AA 220 flame atomic absorption spectrophotometer with graphite furnace, in accordance with the ISO 8288/2001 SR 13315/1996 and SR 8662-2/1997 standards. Sample results are reported to completely dry soil.

Concentrations of measured physical-chemical indicators were compared with the limits imposed by the Order of the Ministry of Waters, Forests and Environmental Protection no. 756/1997, which establishes for soil normal concentration values (NV), alert threshold (AT) and intervention thresholds (IT). The paper considers the alert (AT) and intervention thresholds (IT) for less sensitive land use categories (thus excluding agricultural areas).

Table 2. Locations where average concentration of copper ( $\mathrm{mg} / \mathrm{kg}$ dry soil) indicated varying pollution intensity degrees

\begin{tabular}{|c|c|c|c|c|c|c|c|c|}
\hline Location & $\begin{array}{c}\text { Number } \\
\text { of } \\
\text { samples }\end{array}$ & Average & $\mathrm{PI} \%$ & $N V=20$ & $A T=250$ & $\mathrm{IT}=2000$ & $\begin{array}{c}\text { Reliability } \\
\text { Grade }\end{array}$ & Effects \\
\hline Suceava $(0-5 \mathrm{~cm})$ & 7 & 51.15 & -43.8 & NV $=20$ & AT $=250$ & $\mathrm{IT}=2000$ & 1 & Pollution level - Very bad \\
\hline Suceava $(5-30 \mathrm{~cm})$ & 4 & 44.9 & -38.4 & $\mathrm{NV}=\mathbf{2 0}$ & AT $=250$ & $\mathrm{IT}=2000$ & 1 & Pollution level - Very bad \\
\hline Siret $(0-5 \mathrm{~cm})$ & 4 & 37.5 & -30.4 & $\mathrm{NV}=\mathbf{2 0}$ & AT $=250$ & $\mathrm{IT}=2000$ & 1 & Pollution level - Very bad \\
\hline Siret $(5-30 \mathrm{~cm})$ & 4 & 44.8 & -38.2 & NV $=20$ & $\mathrm{AT}=\mathbf{2 5 0}$ & $I T=2000$ & 1 & Pollution level - Very bad \\
\hline Radauti $(0-5 \mathrm{~cm})$ & 3 & 84.2 & -61.6 & $\mathrm{NV}=\mathbf{2 0}$ & AT $=250$ & $\mathrm{IT}=2000$ & 1 & Pollution level - Very bad \\
\hline Radauti $(5-30 \mathrm{~cm})$ & 3 & 75.1 & -57.9 & NV $=\mathbf{2 0}$ & $\mathrm{AT}=\mathbf{2 5 0}$ & $\mathrm{IT}=2000$ & 1 & Pollution level - Very bad \\
\hline Falticeni $(0-5 \mathrm{~cm})$ & 3 & 71.7 & -56.4 & $\mathrm{NV}=\mathbf{2 0}$ & $\mathrm{AT}=\mathbf{2 5 0}$ & $\mathrm{IT}=2000$ & 1 & Pollution level - Very bad \\
\hline Falticeni $(5-30 \mathrm{~cm})$ & 3 & 71.3 & -56.2 & $\mathrm{NV}=\mathbf{2 0}$ & AT $=250$ & $\mathrm{IT}=2000$ & 1 & Pollution level - Very bad \\
\hline Gura Humorului( $0-5 \mathrm{~cm})$ & 3 & 33.7 & -25.5 & $\mathrm{NV}=\mathbf{2 0}$ & AT $=250$ & $\mathrm{IT}=2000$ & 1 & Pollution level - Very bad \\
\hline Gura Humorului(5-30cm) & 3 & 25.7 & -12.4 & NV $=20$ & AT $=250$ & $\mathrm{IT}=2000$ & 3 & Pollution level - Bad \\
\hline Campulung Moldovenesc $(0-5 \mathrm{~cm})$ & 2 & 68.6 & -54.8 & $\mathrm{NV}=\mathbf{2 0}$ & AT $=250$ & $\mathrm{IT}=2000$ & 1 & Pollution level - Very bad \\
\hline Campulung Moldovenesc $(5-30 \mathrm{~cm})$ & 2 & 64.2 & -53.5 & NV $=\mathbf{2 0}$ & $\mathrm{AT}=\mathbf{2 5 0}$ & $\mathrm{IT}=2000$ & 1 & Pollution level - Very bad \\
\hline Vatra Dornei $(0-5 \mathrm{~cm})$ & 1 & 27.6 & -15.9 & NV $=20$ & $\mathrm{AT}=\mathbf{2 5 0}$ & $\mathrm{IT}=2000$ & 1 & Pollution level - Very bad \\
\hline Vatra Dornei $(5-30 \mathrm{~cm})$ & 1 & 25.1 & -11.3 & $\mathrm{NV}=\mathbf{2 0}$ & AT $=250$ & $\mathrm{IT}=2000$ & 3 & Pollution level - Bad \\
\hline
\end{tabular}

Table 3a. Locations where average concentration of zinc $(\mathrm{mg} / \mathrm{kg}$ dry soil) indicated varying pollution intensity degrees

\begin{tabular}{|c|c|c|c|c|c|c|c|c|}
\hline Location & $\begin{array}{c}\text { Number } \\
\text { of } \\
\text { samples }\end{array}$ & Average & $\mathrm{PI} \%$ & $N V=100$ & $\mathrm{AT}=700$ & $\mathrm{IT}=1500$ & $\begin{array}{c}\text { Reliability } \\
\text { Grade }\end{array}$ & Effects \\
\hline Suceava $(0-5 \mathrm{~cm})$ & 7 & 160.9 & -23.3 & NV $=100$ & AT $=700$ & IT $=1500$ & 1 & Pollution level - Very bad \\
\hline Suceava $(5-30 \mathrm{~cm})$ & 4 & 413.3 & -61.0 & $\mathrm{NV}=100$ & AT $=700$ & $\mathrm{IT}=1500$ & 1 & Pollution level - Very bad \\
\hline Rădăuţi(0-5cm) & 3 & 149.9 & -19.9 & $\mathrm{NV}=100$ & AT $=700$ & $\mathrm{IT}=1500$ & 1 & Pollution level - Very bad \\
\hline Rădăuţi(5-30cm) & 3 & 269.4 & -45.9 & NV $=100$ & AT $=700$ & $\mathrm{IT}=1500$ & 1 & Pollution level - Very bad \\
\hline Câmpulung Moldovenesc $(0-5 \mathrm{~cm})$ & 2 & 124.1 & -10.8 & NV $=100$ & AT $=700$ & $\mathrm{IT}=1500$ & 3 & Pollution level - Bad \\
\hline Câmpulung Moldovenesc $(5-30 \mathrm{~cm})$ & 2 & 123.6 & -10.5 & NV $=100$ & AT $=700$ & $\mathrm{IT}=1500$ & 3 & Pollution level - Bad \\
\hline Vatra Dornei $(0-5 \mathrm{~cm})$ & 1 & 158.8 & -15.9 & $\mathrm{NV}=100$ & AT $=700$ & IT $=1500$ & 1 & Pollution level - Very bad \\
\hline Vatra Dornei(5-30cm) & 1 & 128.9 & -12.6 & $\mathrm{NV}=100$ & AT $=700$ & $\mathrm{IT}=1500$ & 3 & Pollution level - Bad \\
\hline
\end{tabular}


Table 3b. Instance of significant exceedance of zinc concentration in soil

\begin{tabular}{|c|c|c|c|c|c|c|c|c|c|}
\hline $\begin{array}{l}\text { Suceava } \\
\text { Location }\end{array}$ & $\begin{array}{c}\text { Suceava River } \\
\text { bank }\end{array}$ & $\begin{array}{c}\text { Suceava River } \\
\text { bank }\end{array}$ & $\begin{array}{c}\text { Downstream } \\
\text { Suceava MSW } \\
\text { landfill }\end{array}$ & $\begin{array}{c}\text { Adjaicent to } \\
\text { Suceava MSW } \\
\text { landfill }\end{array}$ & \multirow{3}{*}{ Average } & \multirow{3}{*}{$\mathrm{Pl} \%$} & \multirow[t]{2}{*}{ NV } & \multirow[t]{2}{*}{ AT } & \multirow[t]{2}{*}{ IT } \\
\hline Date & 6.05 .2005 & 24.04 .2007 & 24.04 .2007 & 22.03 .2012 & & & & & \\
\hline $\begin{array}{l}\text { Sampling } \\
\text { Depth }\end{array}$ & $5-30 \mathrm{~cm}$ & $5-30 \mathrm{~cm}$ & $5-30 \mathrm{~cm}$ & $5-30 \mathrm{~cm}$ & & & \multirow[t]{2}{*}{100} & \multirow[t]{2}{*}{700} & \multirow[t]{2}{*}{1500} \\
\hline $\mathrm{Zn}$ & 56.73 & 90.77 & 1447 & 59 & 413.3 & -61.0 & & & \\
\hline
\end{tabular}

Table 4. Locations where average concentration of chromium $(\mathrm{mg} / \mathrm{kg}$ dry soil) indicated varying pollution intensity degrees

\begin{tabular}{|c|c|c|c|c|c|c|c|c|}
\hline Location & $\begin{array}{l}\text { Number } \\
\text { of } \\
\text { samples }\end{array}$ & Average & $\mathrm{PI} \%$ & $N V=30$ & $\mathrm{AT}=\mathbf{3 0 0}$ & $\mathrm{IT}=600$ & $\begin{array}{l}\text { Reliabilit } \\
\text { y Grade }\end{array}$ & Effects \\
\hline Suceava $(0-5 \mathrm{~cm})$ & 7 & 46.9 & -21.9 & $\mathrm{NV}=\mathbf{3 0}$ & AT $=300$ & IT $=600$ & 1 & Pollution level - Very bad \\
\hline Suceava $(5-30 \mathrm{~cm})$ & 4 & 43.7 & -18.5 & $\mathrm{NV}=\mathbf{3 0}$ & AT $=300$ & $\mathrm{IT}=600$ & 1 & Pollution level - Very bac \\
\hline Siret $(0-5 \mathrm{~cm})$ & 4 & 36.6 & -9.9 & NV $=30$ & $A T=300$ & $\mathrm{IT}=600$ & 3 & Pollution level - Bad \\
\hline Siret $(5-30 \mathrm{~cm})$ & 4 & 57.2 & -31.2 & $N V=30$ & AT $=300$ & $\mathrm{IT}=600$ & 1 & Pollution level - Very bad \\
\hline Rădăuţi(0-5cm) & 3 & 43.7 & -18.6 & $N V=30$ & $A T=300$ & $\mathrm{IT}=600$ & 1 & Pollution level - Very bad \\
\hline Rădăuţi(5-30cm) & 3 & 37.6 & -11.2 & $\mathrm{NV}=\mathbf{3 0}$ & AT $=300$ & $\mathrm{IT}=600$ & 3 & Pollution level - Bad \\
\hline Fălticeni $(0-5 \mathrm{~cm})$ & 3 & 28.6 & 2.4 & $\mathrm{NV}=\mathbf{3 0}$ & $\mathrm{AT}=300$ & $\mathrm{IT}=600$ & 5 & Pollution level - Medium \\
\hline Fălticeni $(5-30 \mathrm{~cm})$ & 3 & 34.9 & -7.7 & $\mathrm{NV}=\mathbf{3 0}$ & AT $=300$ & $\mathrm{IT}=600$ & 3 & Pollution level - Bad \\
\hline Gura Humorului( $0-5 \mathrm{~cm})$ & 3 & 22.8 & 13.7 & $N V=30$ & AT $=300$ & $\mathrm{IT}=600$ & 5 & Pollution level - Medium \\
\hline Gura Humorului(5-30cm) & 3 & 26.8 & 5.7 & $\mathrm{NV}=\mathbf{3 0}$ & AT $=300$ & $\mathrm{IT}=600$ & 5 & Pollution level - Medium \\
\hline Câmpulung Moldovenesc $(0-5 \mathrm{~cm})$ & 2 & 56.8 & -30.8 & $\mathrm{NV}=\mathbf{3 0}$ & $A T=300$ & $\mathrm{IT}=600$ & 1 & Pollution level - Very bad \\
\hline Câmpulung Moldovenesc $(5-30 \mathrm{~cm})$ & 2 & 56.7 & -30.8 & $\mathrm{NV}=\mathbf{3 0}$ & $\mathrm{AT}=300$ & $\mathrm{IT}=600$ & 1 & Pollution level - Very bad \\
\hline
\end{tabular}

Table 5a. Locations where average concentration of cadmium $(\mathrm{mg} / \mathrm{kg}$ dry soil) indicated varying pollution intensity degrees

\begin{tabular}{|l|c|c|c|c|c|c|c|l|}
\hline Location & $\begin{array}{c}\text { Number of } \\
\text { samples }\end{array}$ & Average & PI\% & NV = 1 & AT = 5 & IT = 10 & Reliability Grade & Effects \\
\hline Suceava $(5-30 \mathrm{~cm})$ & 4 & $\mathbf{0 . 9 6}$ & 2.3 & NV = 1 & AT = 5 & IT = 10 & 5 & Pollution level - Medium \\
\hline Radauti $(0-5 \mathrm{~cm})$ & 3 & 36.1 & -0.02 & NV = 1 & AT = 5 & IT = 10 & 3 & Pollution level - Bad \\
\hline
\end{tabular}

Table. $\mathbf{5 b}$ - Instance of significant exceedance of cadmium concentration in soil

\begin{tabular}{|c|c|c|c|c|c|c|c|c|}
\hline Radauti Location & $\begin{array}{c}\text { Adjacent } \\
\text { to Radauti } \\
\text { MSW } \\
\text { landfill }\end{array}$ & $\begin{array}{l}\text { Adjacent to } \\
\text { Radauti } \\
\text { MSW landfill }\end{array}$ & $\begin{array}{l}\text { Adjaicent to } \\
\text { Radauti } \\
\text { MSW landfill }\end{array}$ & Average & $\mathrm{Pl} \%$ & \multirow{6}{*}{$N V=1$} & \multirow{6}{*}{$A T=5$} & \multirow{6}{*}{$\mathrm{IT}=10$} \\
\hline Date & 12.05 .2006 & 16.08 .2007 & 20.04 .2010 & & & & & \\
\hline Depth $(\mathrm{cm})$ & $0-5 \mathrm{~cm}$ & $0-5 \mathrm{~cm}$ & $0-5 \mathrm{~cm}$ & $0-5 \mathrm{~cm}$ & $0-5 \mathrm{~cm}$ & & & \\
\hline $\begin{array}{l}\mathrm{Cd}(\mathrm{mg} / \mathrm{kg} \text { dry } \\
\text { soil) }\end{array}$ & 107.86 & 0.3 & 0.3 & 36.2 & -0.02 & & & \\
\hline Depth $(\mathrm{cm})$ & $5-30 \mathrm{~cm}$ & $5-30 \mathrm{~cm}$ & $5-30 \mathrm{~cm}$ & $5-30 \mathrm{~cm}$ & $5-30 \mathrm{~cm}$ & & & \\
\hline $\begin{array}{l}\mathrm{Cd}(\mathrm{mg} / \mathrm{kg} \text { dry } \\
\text { soil) }\end{array}$ & 107.86 & 0.3 & 0.3 & 36.2 & -0.02 & & & \\
\hline
\end{tabular}

Table. 6a Locations where average concentration of cobalt $(\mathrm{mg} / \mathrm{kg}$ dry soil) indicated varying pollution intensity degrees

\begin{tabular}{|c|c|c|c|c|c|c|c|c|}
\hline Location & $\begin{array}{c}\text { Number } \\
\text { of } \\
\text { samples }\end{array}$ & Average & $\mathrm{PI} \%$ & $\mathrm{NV}=15$ & $A T=100$ & $\mathrm{IT}=\mathbf{2 5 0}$ & $\begin{array}{c}\text { Reliability } \\
\text { Grade }\end{array}$ & Effects \\
\hline Suceava $(0-5 \mathrm{~cm})$ & 7 & 12.3 & 9.5 & $\mathrm{NV}=15$ & AT $=100$ & $\mathrm{IT}=250$ & 5 & Pollution level - Very bad \\
\hline Suceava $(5-30 \mathrm{~cm})$ & 4 & 19.6 & -13.2 & $N V=15$ & AT $=100$ & $\mathrm{IT}=250$ & 3 & Pollution level - Bad \\
\hline Siret $(5-30 \mathrm{~cm})$ & 4 & 11.9 & 11.5 & $\mathrm{NV}=15$ & AT $=100$ & $\mathrm{IT}=250$ & 5 & Pollution level - Medium \\
\hline Radauti $(0-5 \mathrm{~cm})$ & 3 & 24.3 & -23.7 & $\mathrm{NV}=15$ & $\mathrm{AT}=100$ & $\mathrm{IT}=250$ & 1 & Pollution level - Very bad \\
\hline Radauti $(5-30 \mathrm{~cm})$ & 3 & 20.2 & -14.9 & $\mathrm{NV}=15$ & AT $=100$ & $\mathrm{IT}=250$ & 3 & Pollution level - Bad \\
\hline Falticeni $(0-5 \mathrm{~cm})$ & 3 & 26.2 & -27.3 & NV $=15$ & AT $=100$ & $\mathrm{IT}=250$ & 1 & Pollution level - Very bad \\
\hline Gura Humorului $(0-5 \mathrm{~cm})$ & 3 & 24.3 & -23.6 & $\mathrm{NV}=15$ & AT $=100$ & $\mathrm{IT}=250$ & 1 & Pollution level - Very bad \\
\hline Gura Humorului $(5-30 \mathrm{~cm})$ & 3 & 25.9 & -26.7 & $\mathrm{NV}=15$ & $\mathrm{AT}=100$ & $\mathrm{IT}=250$ & 1 & Pollution level - Very bad \\
\hline Campulung Moldovenesc $(0-5 \mathrm{~cm})$ & 2 & 14.8 & 0.8 & $\mathrm{NV}=15$ & AT $=100$ & $\mathrm{IT}=250$ & 5 & Pollution level - Medium \\
\hline Campulung Moldovenesc $(5-30 \mathrm{~cm})$ & 2 & 14.0 & 3.4 & $\mathrm{NV}=15$ & $\mathrm{AT}=100$ & $\mathrm{IT}=250$ & 5 & Pollution level - Medium \\
\hline Vatra Dornei $(0-5 \mathrm{~cm})$ & 1 & 108.9 & -75.8 & $N V=15$ & AT $=100$ & $\mathrm{IT}=250$ & 1 & Pollution level - Very bad \\
\hline Vatra Dornei $(5-30 \mathrm{~cm})$ & 1 & 58.4 & -59.1 & NV $=15$ & AT $=100$ & $\mathrm{IT}=\mathbf{2 5 0}$ & 1 & Pollution level - Very bad \\
\hline
\end{tabular}


Table 6b. Instance of significant exceedance of cobalt concentration in soil

\begin{tabular}{|c|c|c|c|c|c|c|c|c|}
\hline Falticeni location & $\begin{array}{c}\text { Adjacent to } \\
\text { Falticeni MSW } \\
\text { landfill }\end{array}$ & $\begin{array}{c}\text { Adjacent to } \\
\text { Falticeni MSW } \\
\text { landfill }\end{array}$ & $\begin{array}{c}\text { Adjacent to } \\
\text { Falticeni MSW } \\
\text { landfill }\end{array}$ & \multirow[t]{3}{*}{ NV } & \multirow[t]{3}{*}{ AT } & \multirow[t]{3}{*}{ IT } & \multirow{3}{*}{$\begin{array}{l}\text { Averag } \\
\text { e }\end{array}$} & \multirow[t]{3}{*}{$\mathrm{Pl} \%$} \\
\hline Date & 03.05 .2006 & 14.08 .2007 & 10.06 .2009 & & & & & \\
\hline Depth $(\mathrm{cm})$ & $5-30 \mathrm{~cm}$ & $5-30 \mathrm{~cm}$ & $5-30 \mathrm{~cm}$ & & & & & \\
\hline Co (mg/kg dry soil) & 11.21 & 101.51 & 7.81 & 15 & 100 & 250 & 40.2 & -45.6 \\
\hline
\end{tabular}

Table 6c. Instance of significant exceedance of cobalt concentration in soil

\begin{tabular}{|l|l|l|l|l|l|}
\hline Depth $(0-5 \mathrm{~cm})$ & Adjacent to Vatra Dornei MSW landfill - 16.05.2006 & NV & AT & IT & PI\% \\
\hline Co $(\mathrm{mg} / \mathrm{kg}$ dry soil) & 108.94 & $\mathbf{1 5}$ & 100 & 250 & -75.8 \\
\hline
\end{tabular}

Table 7a. Locations where average concentration of nickel ( $\mathrm{mg} / \mathrm{kg}$ dry soil) indicated varying pollution intensity degrees

\begin{tabular}{|c|c|c|c|c|c|c|c|c|}
\hline Location & $\begin{array}{c}\text { Number } \\
\text { of } \\
\text { samples }\end{array}$ & Average & $\mathrm{Pl} \%$ & $N V=20$ & $A T=200$ & $\mathrm{IT}=500$ & $\begin{array}{l}\text { Reliability } \\
\text { Grade }\end{array}$ & Effects \\
\hline Suceava $(0-5 \mathrm{~cm})$ & 7 & 60.1 & -50.0 & $N V=20$ & AT $=200$ & IT $=500$ & 1 & Pollution level - Very bad \\
\hline Suceava $(5-30 \mathrm{~cm})$ & 4 & 66.8 & -53.9 & $\mathrm{NV}=\mathbf{2 0}$ & AT $=200$ & $\mathrm{IT}=500$ & 1 & Pollution level - Very bad \\
\hline Siret $(0-5 \mathrm{~cm})$ & 4 & 27.2 & -15.3 & $\mathrm{NV}=\mathbf{2 0}$ & AT $=200$ & $\mathrm{IT}=500$ & 1 & Pollution level - Very bad \\
\hline Siret $(5-30 \mathrm{~cm})$ & 4 & 43.6 & -37.1 & $\mathrm{NV}=\mathbf{2 0}$ & AT $=200$ & $\mathrm{IT}=500$ & 1 & Pollution level - Very bad \\
\hline Radauti $(0-5 \mathrm{~cm})$ & 3 & 139.4 & -74.9 & $\mathrm{NV}=\mathbf{2 0}$ & AT $=200$ & $\mathrm{IT}=500$ & 1 & Pollution level - Very bad \\
\hline Radauti(5-30cm) & 3 & 45.5 & -38.9 & $\mathrm{NV}=\mathbf{2 0}$ & AT $=200$ & $\mathrm{IT}=500$ & 1 & Pollution level - Very bad \\
\hline Falticeni(5-30cm) & 3 & 38.3 & -31.4 & $\mathrm{NV}=\mathbf{2 0}$ & AT $=200$ & $\mathrm{IT}=500$ & 1 & Pollution level - Very bad \\
\hline Gura Humorului( $0-5 \mathrm{~cm})$ & 3 & 56.9 & -47.9 & NV $=\mathbf{2 0}$ & AT $=200$ & $\mathrm{IT}=500$ & 1 & Pollution level - Very bad \\
\hline Gura Humorului(5-30cm) & 3 & 57.7 & -48.5 & $\mathrm{NV}=\mathbf{2 0}$ & AT $=200$ & $\mathrm{IT}=500$ & 1 & Pollution level - Very bad \\
\hline Campulung Moldovenesc $(0-5 \mathrm{~cm})$ & 2 & 54.4 & -46.2 & $\mathrm{NV}=\mathbf{2 0}$ & AT $=200$ & $\mathrm{IT}=500$ & 1 & Pollution level - Very bad \\
\hline Campulung Moldovenesc $(5-30 \mathrm{~cm})$ & 2 & 62.5 & -51.5 & $\mathrm{NV}=\mathbf{2 0}$ & AT $=200$ & $\mathrm{IT}=500$ & 1 & Pollution level - Very bad \\
\hline Vatra Dornei $(0-5 \mathrm{~cm})$ & 1 & 32.5 & -23.8 & $\mathrm{NV}=\mathbf{2 0}$ & AT $=200$ & $\mathrm{IT}=500$ & 1 & Pollution level - Very bad \\
\hline Vatra Dornei(5-30cm) & 1 & 36.2 & -28.9 & $N V=20$ & AT $=200$ & IT $=500$ & 1 & Pollution level - Very bad \\
\hline
\end{tabular}

Table 7b. Instance of significant exceedance of nickel concentration in soil

\begin{tabular}{|c|c|c|c|c|c|c|c|c|}
\hline Location & $\begin{array}{c}\text { Adjacent to Radauti } \\
\text { MSW landfill }\end{array}$ & $\begin{array}{c}\text { Adjacent to Radauti } \\
\text { MSW landfill }\end{array}$ & $\begin{array}{c}\text { Adjacent to Radauti } \\
\text { MSW landfill }\end{array}$ & \multirow{3}{*}{ NV } & \multirow{3}{*}{ AT } & \multirow{3}{*}{ IT } & \multirow{3}{*}{ Average } & \multirow{3}{*}{$\mathrm{PI} \%$} \\
\hline Date & 12.05 .2006 & 16.08 .2007 & $20.04 . .2010$ & & & & & \\
\hline Depth $(\mathrm{cm})$ & $0-5 \mathrm{~cm}$ & $0-5 \mathrm{~cm}$ & $0-5 \mathrm{~cm}$ & & & & & \\
\hline $\begin{array}{l}\mathrm{Ni} \\
\text { soil) }\end{array}$ & 311.4 & 64.67 & 42 & 20 & 200 & 500 & 139.4 & -74.9 \\
\hline
\end{tabular}

Table 8a. Locations where average concentration of lead $(\mathrm{mg} / \mathrm{kg}$ dry soil) indicated varying pollution intensity degrees

\begin{tabular}{|c|c|c|c|c|c|c|c|c|}
\hline Location & $\begin{array}{c}\text { Number } \\
\text { of } \\
\text { Samples }\end{array}$ & Average & $\mathrm{Pl} \%$ & $N V=\mathbf{2 0}$ & $\mathrm{AT}=\mathbf{2 5 0}$ & $\mathrm{IT}=1000$ & $\begin{array}{c}\text { Reliability } \\
\text { Grade }\end{array}$ & Effects \\
\hline Suceava $(0-5 \mathrm{~cm})$ & 7 & 40.8 & -34.2 & $\mathrm{NV}=\mathbf{2 0}$ & $\mathrm{AT}=250$ & $\mathrm{IT}=1000$ & 1 & Pollution level - Very bac \\
\hline Suceava $(5-30 \mathrm{~cm})$ & 4 & 42.7 & -36.2 & $\mathrm{NV}=\mathbf{2 0}$ & AT $=250$ & $\mathrm{IT}=1000$ & 1 & Pollution level - Very bad \\
\hline Siret $(0-5 \mathrm{~cm})$ & 4 & 122.9 & -72.0 & $\mathrm{NV}=\mathbf{2 0}$ & $\mathrm{AT}=250$ & $\mathrm{IT}=1000$ & 1 & Pollution level - Very bac \\
\hline Siret $(5-30 \mathrm{~cm})$ & 4 & 131.6 & -73.6 & $\mathrm{NV}=\mathbf{2 0}$ & $\mathrm{AT}=250$ & $\mathrm{IT}=1000$ & 1 & Pollution level - Very bac \\
\hline Falticeni $(0-5 \mathrm{~cm})$ & 3 & 43.3 & -36.8 & $\mathrm{NV}=\mathbf{2 0}$ & $\mathrm{AT}=250$ & $\mathrm{IT}=1000$ & 1 & Pollution level - Very bac \\
\hline Falticeni $(5-30 \mathrm{~cm})$ & 3 & 101.7 & -67.1 & $\mathrm{NV}=\mathbf{2 0}$ & $\mathrm{AT}=250$ & $\mathrm{IT}=1000$ & 1 & Pollution level - Very bac \\
\hline Gura Humorului $(0-5 \mathrm{~cm})$ & 3 & 27.6 & -16.0 & NV $=\mathbf{2 0}$ & $\mathrm{AT}=250$ & $\mathrm{IT}=1000$ & 1 & Pollution level - Very bac \\
\hline Gura Humorului $(5-30 \mathrm{~cm})$ & 3 & 28.7 & -17.9 & $\mathrm{NV}=\mathbf{2 0}$ & $\mathrm{AT}=250$ & $\mathrm{IT}=1000$ & 1 & Pollution level - Very bac \\
\hline Campulung Moldovenesc $(0-5 \mathrm{~cm})$ & 2 & 29.2 & -18.6 & $\mathrm{NV}=\mathbf{2 0}$ & $\mathrm{AT}=250$ & $\mathrm{IT}=1000$ & 1 & Pollution level - Very bad \\
\hline Campulung Moldovenesc $(5-30 \mathrm{~cm})$ & 2 & 36.7 & -29.5 & NV $=\mathbf{2 0}$ & $\mathrm{AT}=\mathbf{2 5 0}$ & $\mathrm{IT}=1000$ & 1 & Pollution level - Very bad \\
\hline Vatra Dornei $(0-5 \mathrm{~cm})$ & 1 & 27.5 & -15.8 & $\mathrm{NV}=\mathbf{2 0}$ & $\mathrm{AT}=250$ & $\mathrm{IT}=1000$ & 1 & Pollution level - Very bac \\
\hline Vatra Dornei $(5-30 \mathrm{~cm})$ & 1 & 37.7 & -30.7 & NV $=\mathbf{2 0}$ & $\mathrm{AT}=250$ & $\mathrm{IT}=1000$ & 1 & Pollution level - Very bad \\
\hline
\end{tabular}

Table 8b. Instance of significant exceedance of lead concentration in soil

\begin{tabular}{|l|c|c|c|c|c|c|c|c|c|}
\hline Siret location & 12.05 .2006 & 16.08 .2007 & 03.04 .2009 & 22.03 .2012 & Average & PI\% & NV & AT & IT \\
\hline $\mathrm{Pb}(0-5 \mathrm{~cm})$ & 18 & 7.9 & $\mathbf{2 1 0 . 9}$ & 255 & 122.9 & -72.0 & 20 & 250 & 1000 \\
\hline $\mathrm{Pb}(5-30 \mathrm{~cm})$ & 15.3 & 11.6 & 257.4 & $\mathbf{2 4 2 . 1}$ & 131.6 & -73.6 & 20 & 250 & 1000 \\
\hline
\end{tabular}


Table 9. Locations where average concentration of arsenic ( $\mathrm{mg} / \mathrm{kg}$ dry soil) indicated varying pollution intensity degrees

\begin{tabular}{|c|c|c|c|c|c|c|c|c|}
\hline Location & $\begin{array}{l}\text { Number of } \\
\text { Samples }\end{array}$ & Average & $\mathrm{Pl} \%$ & $N V=5$ & AT $=25$ & $\mathrm{IT}=\mathbf{5 0}$ & $\begin{array}{c}\text { Reliability } \\
\text { Grade }\end{array}$ & Effects \\
\hline Suceava $(0-5 \mathrm{~cm})$ & 7 & 4.4 & 6.1 & $N V=5$ & AT $=25$ & $\mathrm{IT}=50$ & 5 & Pollution level - Medium \\
\hline Suceava $(5-30 \mathrm{~cm})$ & 4 & 6.3 & -11.4 & $N V=5$ & AT $=25$ & $\mathrm{IT}=50$ & 3 & Pollution level - Bad \\
\hline Falticeni $(0-5 \mathrm{~cm})$ & 3 & 7.2 & -18.2 & $N V=5$ & AT $=25$ & $\mathrm{IT}=50$ & 1 & Pollution level - Very bad \\
\hline Falticeni $(5-30 \mathrm{~cm})$ & 3 & 7.3 & -18.7 & $N V=5$ & AT $=25$ & $\mathrm{IT}=50$ & 1 & Pollution level - Very bad \\
\hline Gura Humorului $(0-5 \mathrm{~cm})$ & 3 & 3.9 & 12.1 & NV $=5$ & AT $=25$ & $\mathrm{IT}=50$ & 5 & Pollution level - Medium \\
\hline Gura Humorului $(5-30 \mathrm{~cm})$ & 3 & 4.6 & 4.6 & $N V=5$ & AT $=25$ & $\mathrm{IT}=50$ & 5 & Pollution level - Medium \\
\hline Campulung Moldovenesc $(0-5 \mathrm{~cm})$ & 2 & 5.7 & -6.1 & NV $=5$ & AT $=25$ & $\mathrm{IT}=50$ & 3 & Pollution level - Bad \\
\hline Campulung Moldovenesc $(5-30 \mathrm{~cm})$ & 2 & 5.6 & -5.7 & NV $=5$ & AT $=25$ & $\mathrm{IT}=50$ & 3 & Pollution level - Bad \\
\hline Vatra Dornei $(0-5 \mathrm{~cm})$ & 1 & 10.6 & -35.9 & $N V=5$ & AT $=25$ & $\mathrm{IT}=50$ & 1 & Pollution level - Very bad \\
\hline Vatra Dornei $(5-30 \mathrm{~cm})$ & 1 & 14.1 & -46.7 & NV $=5$ & AT $=25$ & $\mathrm{IT}=50$ & 1 & Pollution level - Very bad \\
\hline
\end{tabular}

Analyzing the results of laboratory measurements in Tab 2 - Tab 9 for different metals and soil horizons, one can observe the following:

for the 0-5 cm horizon:

口Pollution level - Very bad” - with destructive effects on the environment, which requires implementation of decontamination measures for the landfills:

- Suceava, because of high values for copper concentration (PI with values of $-43.8 \%-\mathrm{Tab}$. 2), zinc concentration (PI -23.3\% - Tab. 3a), chromium (PI -21.9\% - Tab. 4), nickel (PI -50.0\% Tab. 7a) and lead concentration (PI -32.2\% - Tab. 8);

- Gura Humorului due to high values found for copper concentration (PI -25.5\% - Tab. 2), cobalt (PI -23.6\% - Tab. 6a), nickel (PI - 47.9\% - Tab. 7a), and lead concentration (IP -16.0\% Tab. 8);

- Radauti (PI for copper concentration - 61.6\% - Tab. 2; PI for zinc concentration - 19.9\% Tab. 3; PI for chromium -18.6\% - Tab. 4; PI for cobalt -23 7\% - Tab. 6a; PI for nickel $-74.9 \%$ Tab. 7);

- Campulung Moldovenesc (PI for copper concentration -54.85\% - Tab. 2; PI for chromium 30.8\% - Tab. 4; PI for nickel -46.2\% - Tab. 7a and PI for lead concentration -18.6\% - Tab. 8);

- Vatra Dornei (PI for copper concentration -15.9\% - Tab. 2; PI for zinc -15.9 - Tab. 3a; PI for cobalt -75.79\% - Tab. 6a; PI for nickel - 23.8\% - Tab. 7a; PI for lead -15.8\% - Tab. 8a and PI for arsenic $-35.85 \%$ - Tab. 9);

¿Pollution level - Bad” for the elements: zinc (PI -10.8\% at Campulung Moldovenesc MSW landfill), chromium (PI $-9.9 \%$ at Siret MSW landfill), cadmium (PI $-0.02 \%$ at Radauti MSW landfill) and arsenic (PI -6.1\% at Campulung Moldovenesc MSW landfill);

口 „Pollution level - Medium” for the elements: chromium at Gura Humorului urban solid waste landfill (PI 13.7\%), cobalt at Suceava MSW landfill (PI of 9.5\%) and Campulung Moldovenesc MSW landfill (PI of 0.8\%), and arsenic at Suceava MSW landfill (PI of 6.1\%) and Gura Humorului urban solid waste landfill (PI 12.1\%).

for the $5-30 \mathrm{~cm}$ horizon:

口 „Pollution level - Very bad”, with destructive effects on the environment, requiring implementation of decontamination measures for the landfills: Suceava (PI for copper $38.4 \%$, for zinc $-61 \%$, for chromium $-18,5 \%$, nickel $-53.9 \%$ and lead $-36.2 \%$ ), Siret (PI for copper $-38.2 \%$, for chromium $-31.2 \%$, nickel $-37.1 \%$ and lead - $73.6 \%$ ), Radauti (PI for copper $-57.9 \%$, zinc $-45.9 \%$ and nickel $-38.9 \%$ ), Falticeni (PI for copper $-56.2 \%$, cobalt $-45.6 \%$, nickel 31.4\%, lead $-67.1 \%$ and arsenic $-18.7 \%$ ), Gura Humorului (PI for cobalt $-26,7 \%$, nickel $-48.5 \%$ and lead 17.9\%), Campulung Moldovenesc (PI for copper -53.5\%, chromium -30.8\%, 51.5\% for nickel and $29.5 \%$ for lead) and Vatra Dornei (PI for nickel - 28.9\%, 30.7\% for lead and $47.6 \%$ for arsenic); 
口 „Pollution level - Bad” for the following landfills: Suceava (PI for cobalt - $13.2 \%$ and arsenic $11.4 \%$ ), the Radauti (PI for chromium $-11.2 \%$ and cobalt $-14.9 \%$ ), Fălticeni (PI for chromium is 7.7\%), Gura Humorului (PI for copper is $12.4 \%$ ), Campulung Moldovenesc (PI for arsenic concentration is $5.7 \%$ ) and Vatra Dornei (PI for copper concentration is $11.3 \%$ and $12.6 \%$ for zinc concentration);

口 „Pollution level - Medium” for landfills like: Suceava (PI of 2.3\% for cadmium concentration), Siret (PI of $11.5 \%$ for cobalt), Gura Humorului (PI of $5.7 \%$ for chromium and $4.6 \%$ for arsenic) and Campulung Moldovenesc (PI of 3.4\% for cobalt).

Analyzing the pollution indexes (PI) average values for the soil samples (Table 2-9 in conjunction with Tab. 1) and their consequent averaging, Figures $14 \mathrm{a}$ and $14 \mathrm{~b}$ resulted, which show that the $0-5 \mathrm{~cm}$ soil horizon is most pronouncedly degraded around Gura Humorului and Radauti urban solid waste landfills (Fig. 14a) and the $5-30 \mathrm{~cm}$ soil horizon around Campulung Moldovenesc and Suceava landfills (Fig. 14b).

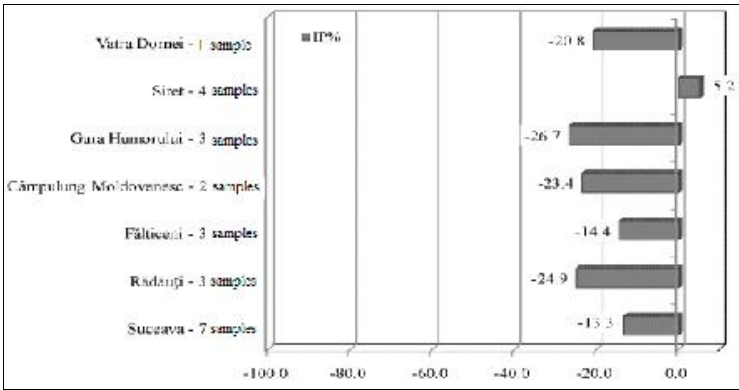

Figure 14a. Average PI\% values for the $0-5 \mathrm{~cm}$ soil horizon

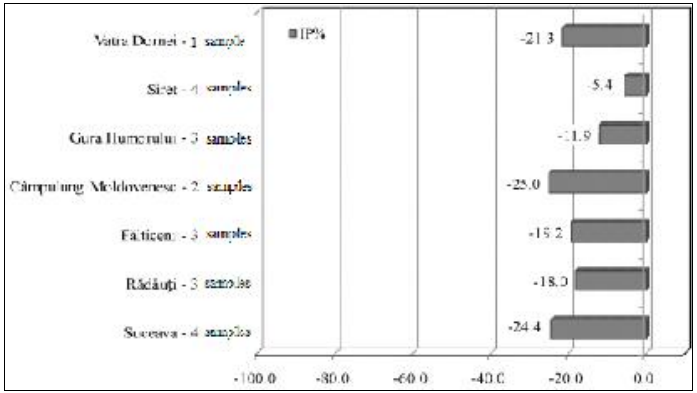

Figure 14b. Average PI\% values for the $5-30 \mathrm{~cm}$ soil horizon

c. Determination of petroleum products in soil was carried out according to the ISO 7877-1/1995 protocol: the soil sample is acidified with sulfuric acid to a $\mathrm{pH}<5$, and extracted with carbon tetrachloride in a Buchi 811 extractor; after evaporation of the solvent, the remaining residue is dissolved in petroleum ether and after solvent evaporation, oil products are determined gravimetrically.

Table 10. Exceedance of petroleum products concentration in the soil

\begin{tabular}{|c|c|c|c|c|c|c|c|c|c|c|}
\hline $\begin{array}{l}\text { Locqtion } \\
\text { Suceava }\end{array}$ & $\begin{array}{l}\text { Suceava } \\
\text { River bank }\end{array}$ & $\begin{array}{l}\text { Suceava } \\
\text { River bank }\end{array}$ & $\begin{array}{l}\text { Suceava } \\
\text { River bank }\end{array}$ & $\begin{array}{c}\text { Downstream } \\
\text { Suceava MSW } \\
\text { landfill }\end{array}$ & $\begin{array}{c}\text { Downstream } \\
\text { Suceava MSW } \\
\text { landfill }\end{array}$ & $\begin{array}{c}\text { Downstream } \\
\text { Suceava MSW } \\
\text { landfill }\end{array}$ & $\begin{array}{l}\text { Adjaicent to } \\
\text { Suceava } \\
\text { MSW landfill }\end{array}$ & \multirow{3}{*}{ NV } & \multirow{3}{*}{ AT } & \multirow{3}{*}{ IT } \\
\hline Date & 6.05 .2005 & 25.07 .2006 & 24.04 .2007 & 18.09 .2006 & 24.04 .2007 & 03.04 .2009 & 22.03 .2012 & & & \\
\hline $\begin{array}{l}\text { Sampling } \\
\text { depth }\end{array}$ & $0-5 \mathrm{~cm}$ & $0-5 \mathrm{~cm}$ & $0-5 \mathrm{~cm}$ & $0-5 \mathrm{~cm}$ & $0-5 \mathrm{~cm}$ & $0-10 \mathrm{~cm}$ & $0-5 \mathrm{~cm}$ & & & \\
\hline $\begin{array}{l}\text { Hydrocarbons } \\
\text { from oil }\end{array}$ & $*$ & $*$ & $*$ & $*$ & $*$ & $*$ & 2600 & $<100$ & 1000 & 2000 \\
\hline $\begin{array}{l}\text { Sampling } \\
\text { depth }\end{array}$ & $5-30 \mathrm{~cm}$ & $5-30 \mathrm{~cm}$ & $5-30 \mathrm{~cm}$ & $5-30 \mathrm{~cm}$ & $5-30 \mathrm{~cm}$ & $5-30 \mathrm{~cm}$ & $5-30 \mathrm{~cm}$ & & & \\
\hline $\begin{array}{l}\text { Hydrocarbons } \\
\text { from oil }\end{array}$ & $*$ & * & * & $*$ & $*$ & * & 3800 & $<100$ & 1000 & 2000 \\
\hline
\end{tabular}

* No sampling or measurements were performed

Analyzing the concentration of petroleum products in the soil (Tab. 10), we found a significant exceedance of the intervention threshold for Suceava MSW landfill, which shows the need for urgent action to remedy the situation.

Except the average statistics used in Tab. 3b, 5b, 6b, 6c, 7b and 8b, several particular situations are given, where analyses revealed exceedance of the AT for some elements in the upper soil horizons (for zinc, at Suceava MSW landfill -Tab. 3b; for cobalt at Fălticeni and Vatra Dornei MSW 
landfills -Tab. 6b, 6c; for nickel at Radauti MSW landfill - Tab. 7b and lead at Siret urban landfill Tab. 8b) or PI (cadmium, the Radauti MSW landfill - Tab. 5b).

\subsubsection{Effects of urban solid waste landfills on water quality}

Water samples were collected from boreholes located in areas adjacent to landfills. These samples were stored and manipulated for further measurements, according to the SR EN ISO 5667-3/2004 standard.

\section{a. Determination of $\mathrm{pH}$}

It was performed according to the SR ISO10523/2009 standard by measuring the activity of hydrogen ions, expressed in pH units, with a WTW $526 \mathrm{pH}$ meter with combined electrode type.

\section{b. Determination of metals}

Concentration measurements of dissolved metals in the water were performed by spectrophotometric method with flame atomic absorption, after filtration of samples, as follows: determination of lead, chromium, copper, zinc and cadmium was conducted according to the ISO $8288 / 2001$ standard. The measurements were performed with a flame atomic absorption spectrophotometer and graphite furnace, spectral type AA 220.

\section{c. Determination of organic substances using the CCO-Cr method}

Determination of Chemical Oxygen Consumption (CCO-Cr) was performed according to the ISO 6060/1996 standard: in a Kjeldahl digester, water samples were mineralized with potassium dichromate in the presence of silver sulfate mixture - sulfuric acid; the excess of potassium dichromate was titrated with iron and ammonium sulfate in the presence of ferroin.

\section{d. Determination of total phosphorus}

Determination of total phosphorus was conducted according to the SR EN ISO 6878/2005 standard, as follows: water samples were treated with a mixture of sulfuric acid - nitric acid; the orthophosphate ions resulted, in the presence of ascorbic acid and ammonium and antimony molybdate form a strong complex of blue color, of which total phosphorus content is measured with a CECIL 8020 spectrophotometer.

e. Determination of ammonia nitrogen (NH4+) was performed according to the STAS 8683-1970 standard: the water sample is buffered at $\mathrm{pH}-7.4$, in order to inhibit the hydrolysis of organic nitrogen compounds. Ammoniacal nitrogen is distilled in a solution of sulfuric acid, of which in an alkaline environment, in the presence of Nessler reagent, ammoniacal nitrogen is determined photometrically with a CECIL 8020 spectrophotometer.

f. Determination of total nitrogen was carried out according to STAS 7312 protocol: in acid environment in the presence of hydrogen peroxide and iron, nitrogen compounds are reduced to ammonia. Following alkalization, the ammonia released is distilled and absorbed in an acid solution, in which the total nitrogen is determined by treating the sample with Nessler reagent, using a CECIL 8020 spectrophotometer.

The results obtained are summarized for MSW Vatra Dornei, Gura Humorului and Suceava in Tables 11-13. 
Table 11. Chemical measurements on water from boreholes in the area adjacent to the Vatra Dornei MSW landfill platform, related pollution indices and effects of pollutants on the environmental factors

\begin{tabular}{|c|c|c|c|c|c|c|c|c|}
\hline $\begin{array}{l}\text { Vatra Dornei: } \\
\text { 20.12.2005 }\end{array}$ & $\begin{array}{l}\text { Borehole } \\
\text { P1 VD* }\end{array}$ & $\begin{array}{c}\text { Borehole } \\
\text { P2 VD* }\end{array}$ & $\begin{array}{l}\text { Average } \\
\text { VD* }\end{array}$ & $\begin{array}{l}\text { Admitted } \\
\text { values** }\end{array}$ & $\begin{array}{c}\text { MU } \\
\text { (measureme } \\
\text { nt unit) }\end{array}$ & $\begin{array}{c}\mathrm{PI} \%= \\
39.96 * * *\end{array}$ & $\begin{array}{c}\text { Reliability } \\
\text { Grade }\end{array}$ & $\begin{array}{l}\text { effects of pollutants on the } \\
\text { environmental factors }\end{array}$ \\
\hline $\mathrm{pH}$ & 7.5 & 7.74 & 7.62 & $\geq 6.5: \leq 9.5$ & unit pH & & & \\
\hline $\mathrm{CCO}-\mathrm{Cr}$ & 279 & 131.47 & 205.24 & 5 & $\mathrm{mg} \mathrm{O}_{2} / \mathrm{l}$ & -95.24 & $\begin{array}{l}\text { No grade } \\
\text { given }\end{array}$ & Pollution level - Catastrophic \\
\hline $\mathrm{CCO}-\mathrm{Mn}$ & 156.43 & 70.73 & 113.58 & - & $\mathrm{mg} \mathrm{O}_{2} / \mathrm{l}$ & & & \\
\hline $\mathrm{H}_{2} \mathrm{~S}^{+} \mathrm{S}_{2}^{-}$ & 0.01 & 0.008 & 0.009 & 0.1 & $\mathrm{mg} / \mathrm{l}$ & 83.49 & 9 & Pollution level - Very good \\
\hline $\mathrm{NH}_{4}^{+}$ & 40.69 & 13.6 & 27.15 & 0.5 & $\mathrm{mg} / \mathrm{l}$ & -96.38 & $\begin{array}{l}\text { No grade } \\
\text { given }\end{array}$ & Pollution level - Catastrophic \\
\hline Total nitrogen & 62.4 & 24.1 & 43.25 & - & $\mathrm{mg} / \mathrm{l}$ & & & \\
\hline Total phosphorus & 5.06 & 2.45 & 3.76 & - & $\mathrm{mg} / \mathrm{l}$ & & & \\
\hline Dissolved lead & 2.25 & 1.535 & 1.89 & 10 & $\mu \mathrm{g} / \mathrm{l}$ & 68.17 & 7 & Pollution level - Good \\
\hline Dissolved chromium & 1.975 & 1.855 & 1.92 & 50 & $\mu \mathrm{g} / \mathrm{l}$ & 92.62 & 9 & Pollution level - Very good \\
\hline Dissolved copper & 17.855 & 2.08 & 9.97 & 100 & $\mu \mathrm{g} / \mathrm{l}$ & 81.87 & 9 & Pollution level - Very good \\
\hline Dissolved zinc & 244.35 & 41.75 & 143.1 & 5000 & $\mu \mathrm{g} / \mathrm{l}$ & 94.44 & 9 & Pollution level - Very good \\
\hline Dissolved cadmium & 0.285 & 0.202 & 0.24 & 5 & $\mu \mathrm{g} / \mathrm{l}$ & 90.71 & 9 & Pollution level - Very good \\
\hline
\end{tabular}

*VD - Vatra Dornei; ** admitted values, according to Law. 458/2002 as amended by Law 311/2004, Government Resolution 11 2010; Law 124/2010; GR 1/2011 (on groundwater quality (drinking water) *** Mean PI\% value/location/measurements may be graded with 7 and indicates a good pollution level - according to Tab. 1

Table 12. Chemical measurements on water from boreholes in the area adjacent to the Gura Humorului urban landfill, related pollution indices and effects of pollutants on the environmental factors

\begin{tabular}{|c|c|c|c|c|c|c|c|c|c|}
\hline $\begin{array}{l}\text { Gura Humorului } \\
14.12 .2005\end{array}$ & $\begin{array}{l}\text { Borehole } \\
\text { P1GH }\end{array}$ & $\begin{array}{l}\text { Borehole } \\
\text { P2GH }\end{array}$ & $\begin{array}{l}\text { Borehole } \\
\text { P3GH }\end{array}$ & $\begin{array}{l}\text { Avera } \\
\text { ge }\end{array}$ & $\begin{array}{l}\text { Admitted } \\
\text { values }\end{array}$ & MU & $\begin{array}{l}\mathrm{PI} \%= \\
51.59^{*}\end{array}$ & $\begin{array}{l}\text { Reliabili } \\
\text { ty grade }\end{array}$ & $\begin{array}{l}\text { effects of pollutants } \\
\text { on the environmental } \\
\text { factors }\end{array}$ \\
\hline $\mathrm{pH}$ & 6.89 & 7.39 & 7.25 & 7.18 & $\geq 6.5: \leq 9.5$ & unit $\mathrm{pH}$ & & - & - \\
\hline $\mathrm{CCO}-\mathrm{Cr}$ & 21.14 & 23.68 & 21.99 & 22.27 & 5 & $\mathrm{mgO}_{2} / \mathrm{l}$ & -63.33 & 1 & $\begin{array}{l}\text { Pollution level - Very } \\
\text { good }\end{array}$ \\
\hline CCO-Mn & 9.68 & 10.09 & 9.89 & 9.89 & - & $\mathrm{mgO}_{2} / \mathrm{l}$ & & & \\
\hline $\mathrm{H}_{2} \mathrm{~S}+\mathrm{S}_{2}^{-}$ & 0.003 & 0.004 & 0.002 & 0.00 & 0.1 & $\mathrm{mg} / \mathrm{l}$ & 94.17 & 9 & $\begin{array}{c}\text { Pollution level - Very } \\
\text { good }\end{array}$ \\
\hline $\mathrm{NH}_{4}^{+}$ & 0.461 & 0.47 & 0.065 & 0.33 & 0.5 & $\mathrm{mg} / \mathrm{l}$ & 20.19 & 7 & Pollution level - Good \\
\hline Total nitrogen & 0.358 & 0.365 & 1.24 & 0.65 & - & $\mathrm{mg} / \mathrm{l}$ & & & \\
\hline Total phosphorus & 0.183 & 0.217 & 0.1 & 0.17 & - & $\mathrm{mg} / \mathrm{l}$ & & & \\
\hline Dissolved lead & 2.62 & 3.07 & 9.14 & 4.94 & 10 & $\mu \mathrm{g} / \mathrm{l}$ & 33.84 & 7 & Pollution level - Good \\
\hline $\begin{array}{l}\text { Dissolved } \\
\text { chromium }\end{array}$ & 1.08 & 1.72 & 0.97 & 1.26 & 50 & $\mu \mathrm{g} / \mathrm{l}$ & 95.10 & 9 & $\begin{array}{c}\text { Pollution level - Very } \\
\text { good }\end{array}$ \\
\hline Dissolved copper & 88.2 & 12.31 & 3.29 & 34.60 & 100 & $\mu \mathrm{g} / \mathrm{I}$ & 48.59 & 7 & Pollution level - Good \\
\hline Dissolved zinc & 233.05 & 42.45 & 16.6 & 97.37 & 5000 & $\mu \mathrm{g} / \mathrm{l}$ & 96.18 & 9 & $\begin{array}{c}\text { Pollution level - Very } \\
\text { good }\end{array}$ \\
\hline $\begin{array}{l}\text { Dissolved } \\
\text { cadmium }\end{array}$ & 0.282 & 0.375 & 0.302 & 0.32 & 5 & $\mu \mathrm{g} / \mathrm{l}$ & 87.98 & 9 & $\begin{array}{l}\text { Pollution level - Very } \\
\text { good }\end{array}$ \\
\hline
\end{tabular}

* Mean PI\% value/location/determinations may be graded with 7, and indicates a good pollution level - according to Tab. 2.

Table 13. Chemical measurements on water from boreholes in the area adjacent to Suceava MSW landfill platform, related pollution indices and effects of pollutants on the environmental factors

\begin{tabular}{|c|c|c|c|c|c|c|c|c|c|c|c|}
\hline $\begin{array}{l}\text { Suceava } \\
6.12 .2005\end{array}$ & $\begin{array}{l}\text { Borehol } \\
\text { e P1Sv }\end{array}$ & $\begin{array}{l}\text { Borehole } \\
\text { P3SV }\end{array}$ & $\begin{array}{l}\text { Borehole } \\
\text { P5SV }\end{array}$ & $\begin{array}{l}\text { Borehole } \\
\text { P7SV }\end{array}$ & $\begin{array}{l}\text { Borehole } \\
\text { P9SV }\end{array}$ & Average & $\begin{array}{l}\text { Admitte } \\
\text { d values }\end{array}$ & MU & $\begin{array}{l}\mathrm{Pl} \%= \\
8.0^{*}\end{array}$ & $\begin{array}{l}\text { Reliabilit } \\
\text { y grade }\end{array}$ & $\begin{array}{c}\text { effects of pollutants on } \\
\text { the environmental } \\
\text { factors }\end{array}$ \\
\hline $\mathrm{pH}$ & 7.25 & 6.89 & 7.81 & 7.31 & 7.25 & 7.30 & $\begin{array}{c}\geq 6.5: \leq \\
9.5\end{array}$ & unit $\mathrm{pH}$ & & & \\
\hline $\mathrm{CCO}-\mathrm{Cr}$ & 92.92 & 155.77 & 779.73 & 740.89 & 111.86 & 376.23 & 5 & $\mathrm{mgO}_{2} / \mathrm{l}$ & 97.38 & $\begin{array}{l}\text { No } \\
\text { grade } \\
\text { given }\end{array}$ & $\begin{array}{l}\text { Pollution level - } \\
\text { Catastrophic }\end{array}$ \\
\hline CCO-Mn & 40.39 & 75.88 & 423.93 & 453.78 & 62.92 & 211.38 & - & $\mathrm{mgO}_{2} / \mathrm{I}$ & & & \\
\hline $\mathrm{H}_{2} \mathrm{~S}^{+} \mathrm{S}_{2}^{-}$ & 0.004 & 0.003 & 0.02 & 0.008 & 0.02 & 0.01 & 0.1 & $\mathrm{mg} / \mathrm{l}$ & 80.18 & 9 & $\begin{array}{c}\text { Pollution level - Very } \\
\text { good }\end{array}$ \\
\hline $\mathrm{NH}_{4}^{+}$ & 1.31 & 13 & 55.43 & 70.67 & 17.11 & 31.50 & 0.5 & $\mathrm{mg} / \mathrm{l}$ & $\begin{array}{c}- \\
96.88\end{array}$ & $\begin{array}{l}\text { No } \\
\text { grade } \\
\text { given }\end{array}$ & $\begin{array}{l}\text { Pollution level - } \\
\text { Catastrophic }\end{array}$ \\
\hline Total nitrogen & 4.88 & 10.09 & 63.2 & 85.8 & 19.1 & 36.61 & - & $\mathrm{mg} / \mathrm{l}$ & & & \\
\hline $\begin{array}{l}\text { Total } \\
\text { phosphorus }\end{array}$ & 0.154 & 0.457 & 2.25 & 2.05 & 0.467 & 1.08 & - & $\mathrm{mg} / \mathrm{l}$ & & & \\
\hline $\begin{array}{l}\text { Dissolved } \\
\text { lead }\end{array}$ & 4.785 & 1.835 & 19.63 & 18.74 & 2.99 & 9.60 & 10 & $\mu \mathrm{g} / \mathrm{l}$ & 2.06 & 5 & $\begin{array}{l}\text { Pollution level - } \\
\text { Medium }\end{array}$ \\
\hline $\begin{array}{l}\text { Dissolved } \\
\text { chromium }\end{array}$ & 1.1 & 9.92 & 67.8 & 200 & 20.61 & 59.89 & 50 & $\mu \mathrm{g} / \mathrm{l}$ & -9.00 & 3 & Pollution level - Bad \\
\hline
\end{tabular}




\begin{tabular}{|c|c|c|c|c|c|c|c|c|c|c|c|}
\hline $\begin{array}{l}\text { Suceava } \\
6.12 .2005\end{array}$ & $\begin{array}{l}\text { Borehol } \\
\text { e P1SV }\end{array}$ & $\begin{array}{l}\text { Borehole } \\
\text { P3SV }\end{array}$ & $\begin{array}{l}\text { Borehole } \\
\text { P5SV }\end{array}$ & $\begin{array}{l}\text { Borehole } \\
\text { P7SV }\end{array}$ & $\begin{array}{l}\text { Borehole } \\
\text { P9SV }\end{array}$ & Average & $\begin{array}{l}\text { Admitte } \\
\mathrm{d} \text { values }\end{array}$ & MU & $\begin{array}{l}\mathrm{Pl} \%= \\
8.0^{*}\end{array}$ & $\begin{array}{l}\text { Reliabilit } \\
\text { y grade }\end{array}$ & $\begin{array}{c}\text { effects of pollutants on } \\
\text { the environmental } \\
\text { factors }\end{array}$ \\
\hline $\begin{array}{l}\text { Dissolved } \\
\text { copper }\end{array}$ & 34.96 & 6.08 & 26.53 & 129.55 & 14.60 & 42.34 & 100 & $\mu \mathrm{g} / \mathrm{l}$ & 40.51 & 7 & Pollution level - Good \\
\hline Dissolved zinc & 581.5 & 130.3 & 296.8 & 251.7 & 18.5 & 255.76 & 5000 & $\mu \mathrm{g} / \mathrm{l}$ & 90.27 & 9 & $\begin{array}{c}\text { Pollution level - Very } \\
\text { good }\end{array}$ \\
\hline $\begin{array}{l}\text { Dissolved } \\
\text { cadmium }\end{array}$ & 1.173 & 0.612 & 1.537 & 3.155 & 0.894 & 1.47 & 5 & $\mu \mathrm{g} / \mathrm{l}$ & 54.46 & 7 & Pollution level - Good \\
\hline
\end{tabular}

Mean PI\% value/location/determinations may be graded with 5 and indicate a medium pollution level - according to Tab. 1

Analyzing the data presented in Tab. 11-13, together with the pollution index average values (PI) in Fig. 15 for the groundwater samples, the following can be observed:

- for water samples collected from boreholes adjacent to Suceava landfill, the $8 \%$ average PI indicates a "medium pollution level" but for indicators like $\mathrm{CCO}-\mathrm{Cr}$ and ammoniacal nitrogen, pollution index values below $95 \%$ indicate a "danger threshold";

- for water samples collected from boreholes adjacent to Vatra Dornei landfills, with average $\mathrm{PI}$ values of $40 \%$, pollution level is "good", but for indicators like CCO-Cr and ammoniacal nitrogen, values of PI lower than $-95 \%$ indicate a "danger threshold" (due to increased domestic organic matter content);

- for water samples collected from boreholes adjacent to Gura Humorului landfills, the average $\mathrm{PI}$ is $51.6 \%$, which indicates a "good pollution level", with the exception of $\mathrm{CCO}-\mathrm{Cr}$ and ammoniacal nitrogen for which the 63, 3\% PI value indicates a „very bad pollution level".

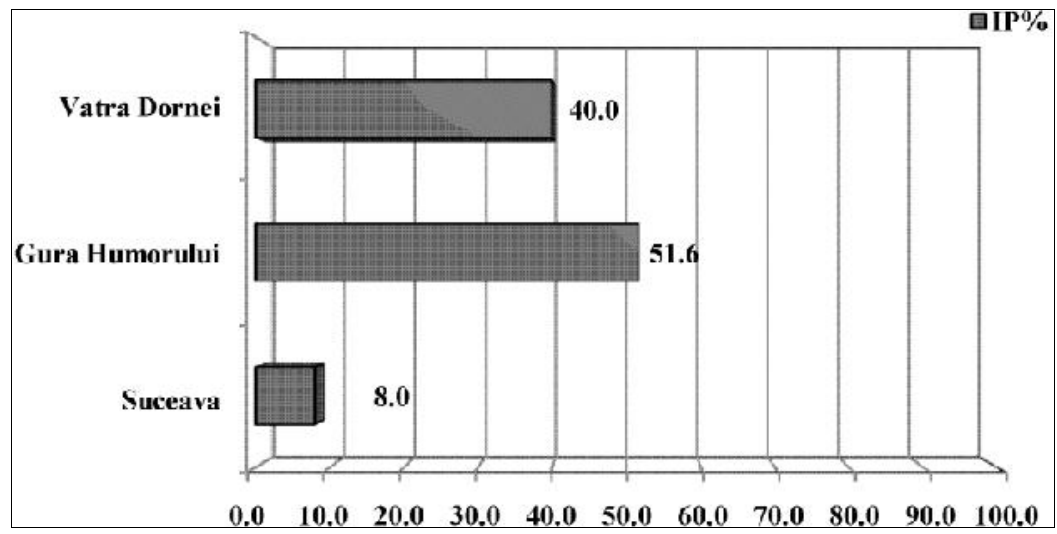

Figure 15. Average PI\% values for groundwater under the MSW landfills.

\section{Conclusions}

Currently, waste management activity in Suceava County is facing a number of problems:

- residential waste collection is not selective, most of it reaching landfills as such, mixed, thus loosing much of its potential usefulness (paper, glass, metals, plastics, textiles etc.);

- existing landfills are often located in sensitive areas (near inhabited areas, surface waters, agricultural land etc.);

u urban waste disposal is performed on bare land; 
most existing urban waste landfills are not operated properly: waste is not compacted and covered periodically with inert materials in order to prevent spread of fire, odors and smoke from waste auto ignition;

- there is no strict control of the quality and quantity of waste entering the landfills;

many landfills are not fenced and neither do they have proper entering points and warning signs;

- landfills are not properly settled from the viewpoint of environmental protection, leading to pollution of air, water and soil in the neighboring areas;

- there are no facilities for produced biogas recovery;

the land occupied by landfills has become degraded land that can no longer be used for agricultural purposes;

pollution indices for most urban landfills in the Suceava County, for some soil and groundwater quality parameters, have "bad" and „very bad" pollution levels, requiring the implementation of ecological restoration measures in those areas.

The problem of waste management in the Suceava county will be resolved by the completion of the project „Integrated management of municipal waste in the Suceava County” by developing the Moara and Pojorata compliant landfills, which will be functional in 2014.

\section{References}

Bularda Gh. et al. 1992. Reziduuri menajere, stradale şi industriale, Tehnică Publishing, Bucharest Cojocaru I. 1995. Surse, procese şi produse de poluare, (pp. 178-186), Junimea Publishing, Iaşi

Diţoiu Valeria, Holban Nina. 2005. Modificări antropice ale mediului, (253-255), Orizonturi Universitare Publishing, Timişoara,

Macoveanu M. 2003. Metode şi tehnici de evaluare a impactului ecologic, Ecozone Publishing, (pp.126-139), laşi,

Rojanschi V., Bran Florina. 2002. Politici şi strategii de mediu, Ed.Economică Publishing (pp. 476477), Bucharest

Rojanschi V., Bran F., Diaconu G. 2002. Protecţia şi ingineria mediului, $2^{\text {nd }}$ edition, Ed. Economică Publishing, (pp. 222-227), Bucharest

***Acord de mediu nr. 9/12.10.2009, A.R.P.M. Bacău (Environment Agreement no. 9/12.10.2009, A.R.P.M. Bacău)

***Anuare privind starea mediului, A. P. M. Suceava (The 2005-2012 Yearbooks on Environmental State, A. P. M. Suceava)

***Directiva $n r$. 2008/98/CE privind deşeurile, (Directive no. 2008/98/CE on waste)

***Directiva nr. 1999/31/EC privind depozitarea deşeurilor, (Directive no. 1999/31/EC on waste disposal)

***Plan Judeţean de Gestiune a Deşeurilor în judeţul Suceava, (County Plan for Waste Management in the Suceava County)

***Standard ISO 11464/2006 - Soil quality. Pretreatment of samples for physico-chemical analyses 
***Standard SR 7184-13/2001 - Soluri. Determinarea pH-ului în suspensii apoase şi saline (masă/volum) şi în pastă la saturaţie, (SR 7184-13/2001 Standard - Soils - Determination of $\mathrm{pH}$ in water and saline suspensions (mass/volume) and in saturated paste)

***Standard SR ISO 11466/1999 - Calitatea solului. Extracţia microelementelor solubile în apa regală, (SR ISO 11466/1999 Standard - Soil Quality. Extraction of soluble trace elements in aqua regia)

***Standard SR ISO 8288/2001 - Calitatea apei. Determinarea conţinutului de cobalt, nichel, cupru, zinc, cadmiu şi plumb. Metoda prin spectrometrie de absorbţie atomic (SR ISO $8288 / 2001$ Standard - Water quality. Determination of cobalt, nickel, copper, zinc, cadmium and lead. Flame atomic absorption spectrometric methods)

***Standard SR ISO 11465/1998 - Calitatea solului. Determinarea conţinutului de substanţă uscată şi de apă, raportat la masă. Metoda gravimetrică, (SR ISO 11465/1998 Standard - Soil quality. Determination of dry matter and water content on a mass basis. Gravimetric method)

***Standard. SR EN ISO 5667-3/2004 - Calitatea apei. Prelevare. Partea 3: Ghid pentru conservarea şi manipularea probelor de apă (SR EN ISO 5667-3/2004 Standard - Water quality - Sampling - Part 3: Guidance on preservation and handling of water samples)

***Standard SR EN 1233/2003 - Calitatea apei. Determinarea cromului. Metode spectrometrice de absorbţie atomică, (Water quality. SR EN 1233/2003 Standard - Determination of chromium. Atomic absorption spectrometric methods)

***SR EN ISO 6878/2005 - Calitatea apei. Determinarea conţinutului de fosfor prin metoda spectrometrică cu molibdat de amoniu. (SR EN ISO 6878/2005 - Water quality Determination of phosphorus - Ammonium molybdate spectrometric method). 